Article

\title{
Not Simply Green: Nature-Based Solutions as a Concept and Practical Approach for Sustainability Studies and Planning Agendas in Cities
}

\author{
Diana Dushkova ${ }^{1}$ and Dagmar Haase ${ }^{1,2, *(D)}$ \\ 1 Department of Geography, Humboldt University Berlin, Unter den Linden 6, 10099 Berlin, Germany; \\ diana.dushkova@geo.hu-berlin.de \\ 2 Helmholtz Centre for Environmental Science-UFZ, Department of Comp. Landscape Ecology, \\ Permoserstr. 15, 04318 Leipzig, Germany \\ * Correspondence: dagmar.haase@geo.hu-berlin.de; Tel.: +49-030-2093-9445
}

Received: 21 December 2019; Accepted: 4 January 2020; Published: 11 January 2020

\begin{abstract}
The concept of a nature-based solution (NBS) has been developed in order to operationalize an ecosystem services approach within spatial planning policies and practices, to fully integrate the ecological dimension, and, at the same time, to address current societal challenges in cities. It exceeds the bounds of traditional approaches that aim 'to protect and preserve' by considering enhancing, restoring, co-creating, and co-designing urban green networks with nature that are characterized by multifunctionality and connectivity. NBSs include the main ideas of green and blue infrastructure, ecosystem services, and biomimicry concepts, and they are considered to be urban design and planning tools for ecologically sensitive urban development. Nowadays, NBSs are on their way to the mainstream as part of both national and international policies. The successful implementation of NBSs in Europe and worldwide, which is becoming increasingly common, highlights the importance and relevance of NBS for sustainable and livable cities. This paper discusses the roles, development processes, and functions of NBSs in cities by taking Leipzig as a case study. Using data from interviews conducted from 2017 to 2019, we study the past and current challenges that the city faces, including the whole process of NBS implementation and successful realization. We discuss the main drivers, governance actors, and design options of NBSs. We highlight the ecosystem services provided by each NBS. We discuss these drivers and governance strategies by applying the framework for assessing the co-benefits of NBSs in urban areas in order to assess the opportunities and challenges that NBSs may have. This way, we are able to identify steps and procedures that help to increase the evidence base for the effectiveness of NBS by providing examples of best practice that demonstrate the multiple co-benefits provided by NBSs.
\end{abstract}

Keywords: urban nature-based solutions; societal challenges; sustainability; ecosystem services; green infrastructure; Leipzig

\section{Introduction}

The concept of nature-based solutions (NBS) has been developed in order to operationalize an ecosystem services approach within spatial planning policies and practices, to fully integrate the ecological dimension, and, at the same time, to address current societal challenges [1,2]. This concept exceeds the bounds of traditional approaches that aim 'to protect and preserve' by considering the enhancing, restoring, co-creating, and co-designing new green networks with nature that are characterized by multifunctionality and connectivity [2,3].

In this context, an NBS includes the main ideas of green and blue infrastructure, ecosystem services, and biomimicry concepts, and it is considered to be an urban design and planning tool 
for ecologically sensitive urban development [3-5]. Defined by the European Commission [4] as "actions [ ... ] and solutions to societal challenges [ ... ] which are inspired by, supported by, or copied from nature", NBSs provide multiple environmental, social, and economic co-benefits at the same time, such as the improvement of place attractiveness, of health and quality of life, the creation of green jobs, etc. An increasing number of scientific publications understand NBSs as a new concept for climate change adaptation and mitigation [6-9].

Thus, NBSs incorporate four interrelated goals. Firstly, they enhance sustainable urbanization by ensuring essential ecosystem functions and by promoting urban regeneration. Secondly, they restore the functionality of degraded ecosystems and their services. Thirdly, they develop aspects of climate change adaptation and mitigation, including the redesign of human-made infrastructure and the integration of gray with green and blue infrastructure. Fourthly, they improve risk management and resilience by utilizing a nature-based design that combines multiple functions and benefits such as pollution reduction, carbon storage, biodiversity conservation, reducing heat stress, and enhanced water retention $[1,3]$.

There has been a growing awareness of NBSs that involve elements of ecosystems and seek to use natural elements to improve the adaptive capacity of human and natural systems by providing ecosystem services to cope with the adverse effects of climate change [6-10]. Nowadays, NBSs are on their way to the mainstream in national and international policies. The successful implementation of NBSs in Europe and worldwide, which are becoming increasingly common, highlights the importance and relevance of NBSs for sustainable and livable cities [5]. A great number of the ongoing EU research framework programme HORIZON 2020 projects endeavor to explore how NBSs work in different urban contexts with regard to the political, social, cultural, institutional, environmental, and economic background.

This paper presents the results of the research within one such project: CONNECTING Nature (COproductioN with NaturE for City Transitioning, INnovation and Governance). CONNECTING Nature is a research and innovation project that aims to accelerate the scaling of NBSs in European cities in which the main idea is to innovate with nature for the development and implementation of NBSs for urban sustainability issues. The CONNECTING Nature project aims to 'co-produce' with scientific partners and different stakeholders-i.e., municipalities, SMEs (small and medium enterprises), NGOs, and citizens-a design framework for the development and implementation of the concrete steps, activities, and tools that are used in the co-production of NBSs. In order to identify the gaps in the existing research and actions on NBS (e.g., EU projects, reference frameworks, and scientific literature on the impact of NBSs), a comprehensive scoping exercise of existing nature-based and grey solutions projects in Europe was carried out within the several working packages of the CONNECTING Nature Project. Thus, the project developed an NBS database that reports a full range of NBS interventions from European cities and creates a basic profile of NBS implementation across Europe. In doing so, it generates and provides knowledge beyond the analysis of various individual NBS projects that have been implemented in cities or urban regions by conducting the first systematic survey and review of NBS interventions in urban environments in Europe. The structural analysis of such a database helps not only to present an overview of urban NBS interventions in Europe but also to identify the limitation, success, and failure factors for NBSs. One of the tasks was to recognize knowledge gaps for research and development in the field of NBSs. The most important ones are:

- lack of knowledge about the potential of NBSs to address the challenges and which to best implement;

- lack of knowledge related to the potential co-benefits that result from NBSs;

- lack of knowledge about the functions nature provides to cities;

- lack of technical knowledge on how to plan, build, and maintain NBSs;

- gaps in the knowledge regarding the different stages of NBS implementation;

- lack of monitoring on the impact of NBS. 
To fill these gaps and allocate resources for producing knowledge for the recognized gaps of the performance of various NBSs, this paper presents the results of the study, focusing in particular on the role, development process (co-creation, co-design, and co-development), and functions of NBS in cities by taking Leipzig as a case study. We aim to explore how the NBS concept at the local level, considering a city that experiences a high dynamic: Leipzig could contribute to bridge the gaps between research and innovation, focusing on nature-based solutions. The specific objectives are to explore how the nature-based solution concept could help link research and innovation in the area of biodiversity and ecosystem services, and what actions are needed to further support the knowledge base for nature-based solutions by presenting key recommendations for overcoming barriers and bridging gaps in order to more effectively uptake and promote NBSs.

Leipzig was selected as a case study of particular interest and exemplary character because the city managed to transform a former industrial area, which had to cope with increasing unemployment rates after industry collapsed, into a green and more liveable place. There are several exemplary NBS cases that are worth considering in the city and that have been addressed for the issues of urban regeneration, coping with former industrial and neglected areas, e.g., brownfields, and the demand for green space for several urban districts, which is currently referred to as the biggest challenge for several cities in Europe and beyond. Firstly, examples of greening initiatives include the creation of wilderness patches in the areas that surround the former industrial area, which are known as New Lake Land (Leipziger Neuseenland). Secondly, green areas also include the central green parts of the city, the floodplains (Leipziger Auenwald), and the renaturation of rivers-which are especially highly polluted during the time of industrialization. Thirdly, a novel network of green-blue interconnected cycling pathways has been implemented, including green roads, green walls, etc., in order to connect the green and blue spaces of the city center with those in the suburban areas.

By considering past and current challenges that Leipzig addresses, we analyze the whole process from the first conception of NBS creation to its implementation and successful realization. The overall aim of this paper is to show and discover more evidence for the effectiveness of NBSs by providing examples of best practices that demonstrate the multiple co-benefits provided by NBSs. In order to achieve this, this paper first presents an analysis of a broad spectrum of NBS cases, explores success factors in the governance of NBSs, and provides a methodology for evaluating NBS case studies. Secondly, this paper compiles case studies that demonstrate the cost-effectiveness and efficiency of the delivery of ecosystem services that have provided an equitable distribution of multiple benefits. Thirdly, we assess the indicators of success and failure, which can be useful when comparing to related issues in other cities.

By providing this analysis, we examine how NBSs relate to existing concepts and sustainability in general as well as what implications can be drawn for NBS research, its applications, and policies. By applying the framework for assessing the co-benefits of NBSs in urban areas developed by [6,9], while also reflecting $[1,10]$ and actualizing within the EU funded H2020 CONNECTING Nature Project impact assessment of NBSs [11], we assess the opportunities and challenges that face NBSs while also addressing all the related issues of urban society and sustainable development.

\section{Study Area}

The city of Leipzig, which is situated in the eastern part of Germany, formerly the socialist GDR, is a "city of extremes" [12]. The city went through a long period of contraction, especially after Germany's reunification in the 1990s when the city lost more than $20 \%$ of its population (about 100,00 inhabitants of lost population). This was due to industrial decline, for example lignite coal industry contraction, job losses, massive out-migration, and a decline in birth rate as well as residential suburbanization into the city's periphery [13]. In the beginning of the 2000s, Leipzig became the capital of "vacant housing", where about $20 \%$ of buildings were vacant $[12,14]$. Due to industrial decline after the reunification of Germany, Leipzig has become famous for thousands of brownfield sites. At the same time, population 
decline led to a sudden improvement of the environmental situation (decontamination and a decrease in air pollution).

From 2000 onwards, shrinkage has become less visible, and since 2010, Leipzig has seen a dynamic regrowth of its population at a rate of about $2 \%$ per year, reaching 600,000 inhabitants in 2019 [7,15]. The extreme population growth of the city has proceeded from about 2010 onward and puts existing green infrastructure, open spaces, and brownfield sites under extreme pressure to be converted into sealed or built space. In this way, it has become necessary to strengthen the ecosystem services in the city and implement new urban NBS initiatives with the goal of improving the quality of the environment and creating a greener, more livable city (Figure 1).

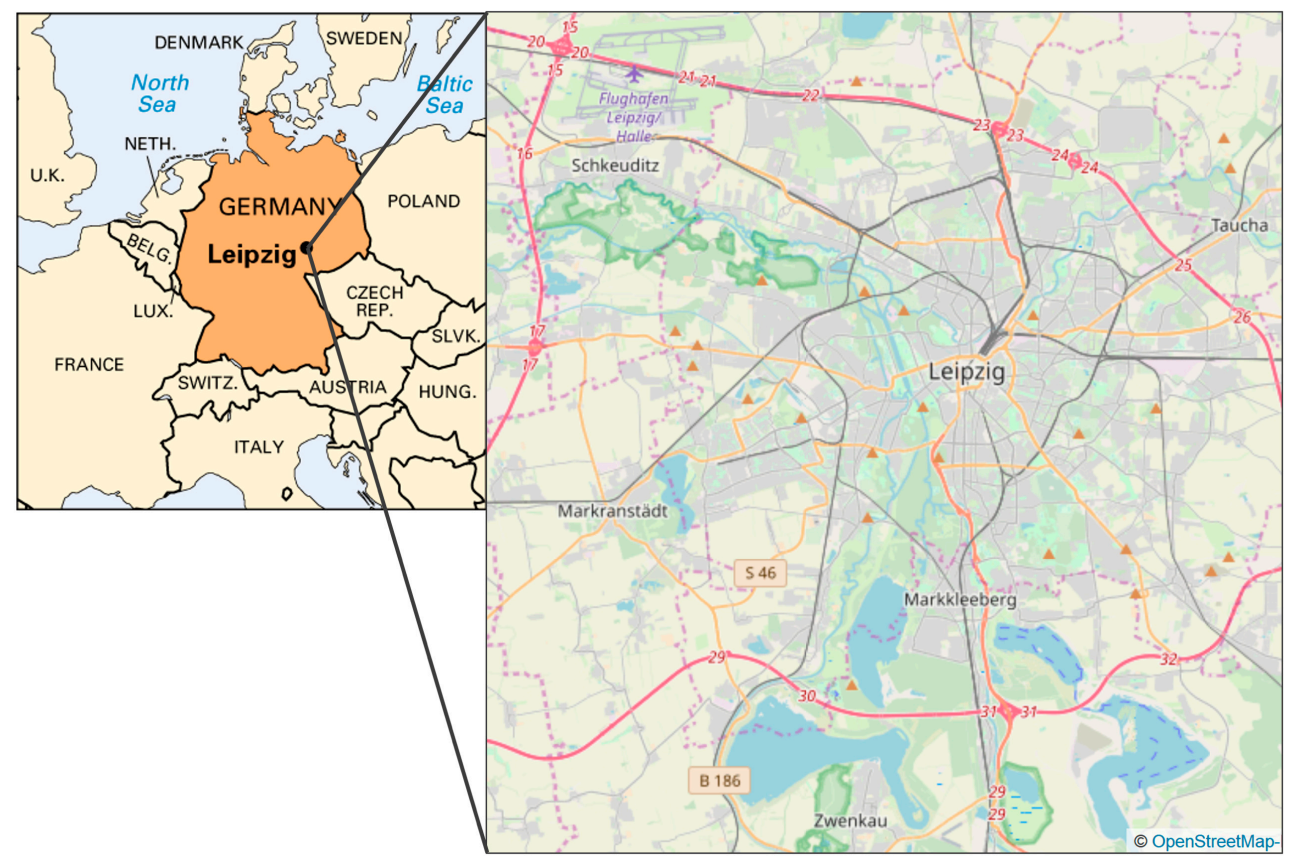

Figure 1. Map of Leipzig (data sources: OpenStreetMap; ArcGIS).

The city currently faces major challenges (Figure 2), including large-scale social, economic, political, and ecological changes over the last 150 years that have been caused by industrialization, the city's socialist past, post-industrial development with active out-migration, and the side effects of rapid development (from a shrinking city to becoming one of Germany's most rapidly growing cities in only a few decades). Other large challenges include changes in Leipzig's natural, semi-natural, and urban landscape, which underline the need to redevelop large open-pit lignite mines on the outskirts of the city, former military training grounds (e.g., to the northeast), and other derelict industrial infrastructures. Environmentally, these challenges also included dealing with the consequences of past industrial uses and landscape changes, including water and air pollution as well as changes to the water system. On the one hand, Leipzig is characterized by extensive and unique urban woodlands, alluvial forests, municipal parks, and garden colonies within easy reach of the city center, as well as by a varied system of rivers, brooks, and recently re-opened canals. On the other hand, its environmental richness came under serious duress during more than a century of heavy industrialization, including large-scale open-pit lignite mines, power stations, and dirty chemical industries.

The second group of challenges includes those caused by environmental risks connected to climate change-i.e., flooding and heat waves. The last big floods in Germany (stemming from the Elbe, Oder, Mulde, and Rhine) drew attention to the fact that technical or manufactured water protection is not $100 \%$ effective, particularly when taking climate change and longer heavy precipitation events into consideration [16,17]. Moreover, with its hazardous bursting of large dams, the last Elbe flood in Germany in 2013 made it very clear that the failure of technological solutions can result in enormous 
damage and casualties. This is because the capacities of technological solutions are enormous in terms of how much water they can hold back, which is much more than any NBS. In this regard, when restoring and maintaining the functionality of wetlands and floodplains or when revitalizing large and smaller rivers NBSs manifest a continuous and more natural inflow and distribution of rainfall water in a larger area and have been shown to improve protection against catastrophic flood events along rivers and coasts [17].

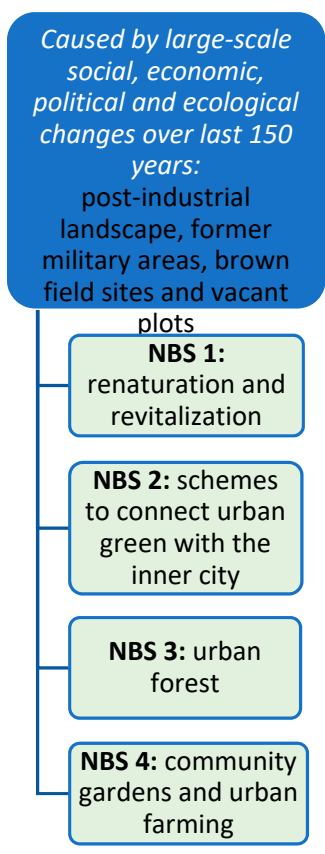

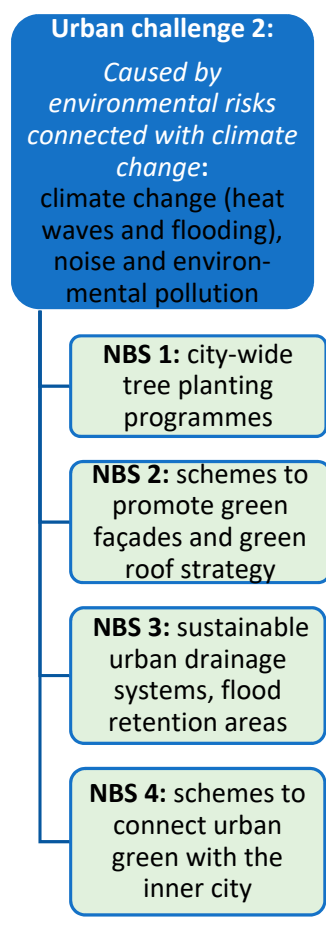

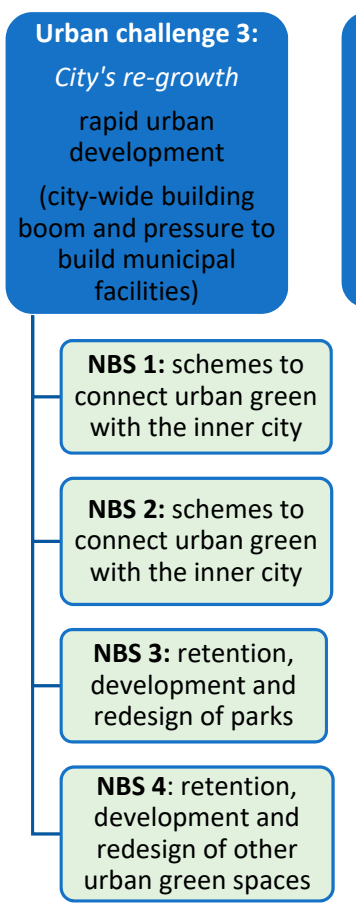

Figure 2. Current major sustainability challenges systematized for the city of Leipzig and related to the nature-based solutions (NBSs) that are the focus of this study (source: authors).

Other sustainability challenges for Leipzig are connected to the stimulation of economic growth, which provides employment opportunities and counteracts population decline and social exclusion alongside emergent socio-spatial differentiation-partly population segregation and what is called ecogentrification-between urban districts. Figure 2 provides an overview of how these challenges are addressed by using the concept of NBS in the case of Leipzig. These challenges will be analyzed in detail in the next sections of the paper.

\section{Material and Methods}

In order to research the selected NBS cases, we analyzed the multiple benefits provided by NBSs. These include benefits related to climate change adaptation and mitigation, the conservation of biodiversity, and the provision of other ecosystem services for human well-being, including benefits to health. For this purpose, we applied the research framework proposed by Raymond et al. [6] that is further developed within the H2020 project CONNECTING Nature and is related to:

(1) Identification of either a problem or a challenge;

(2) Selection and assessment of an NBS and related actions;

(3) Classification and characterization of the NBS design implementation process (including different scales, types, scopes of NBS—see Table 1);

(4) Mapping of NBS potential;

(5) Analysis of governance models of NBS: initiators, actors, and stakeholders involved;

(6) Assessment of indicators for successes and failures when implementing NBSs [18,19]. 
First of all, we conducted a literature review on conceptualizations, approaches, and lessons about the co-creation, co-production, and co-development of NBSs, with a specific focus on application in cities. Then, we applied the analysis of environmental and urban development reports and white papers on NBS-related issues in Leipzig. This was followed by a focused review of the literature and reports on existing NBS governance models in cities, drawing on the governance work of other NBS-related projects such as Nature4Cities [20], Naturvation [10,21], and an analysis of dominant governance modes of NBS interventions presented in the Connecting Nature database [11,22].

In addition, semi-structured interviews were conducted using a questionnaire developed as part of the research work within CONNECTING Nature. We interviewed experts on emergent, innovative, and novel NBS experiments. The interviews were supplemented by site visits and participant observation including those during open public events, urban festivals, public lectures, guided excursions, and other events.

In order to conduct interviews, we applied templates (questionnaires) developed by the Connecting Nature WP2 lead partners from DRIFT (Dutch Institute for Transition Rotterdam). The aim of these interviews was to learn from experts on NBS experiments who were implementing NBS experiments in Leipzig (Figure 3). By analyzing their approaches to the co-production of the design and implementation of their NBS cases, we endeavored to identify lessons learned that will benefit other cities and stakeholders who are interested in designing, implementing, and stewarding NBSs.

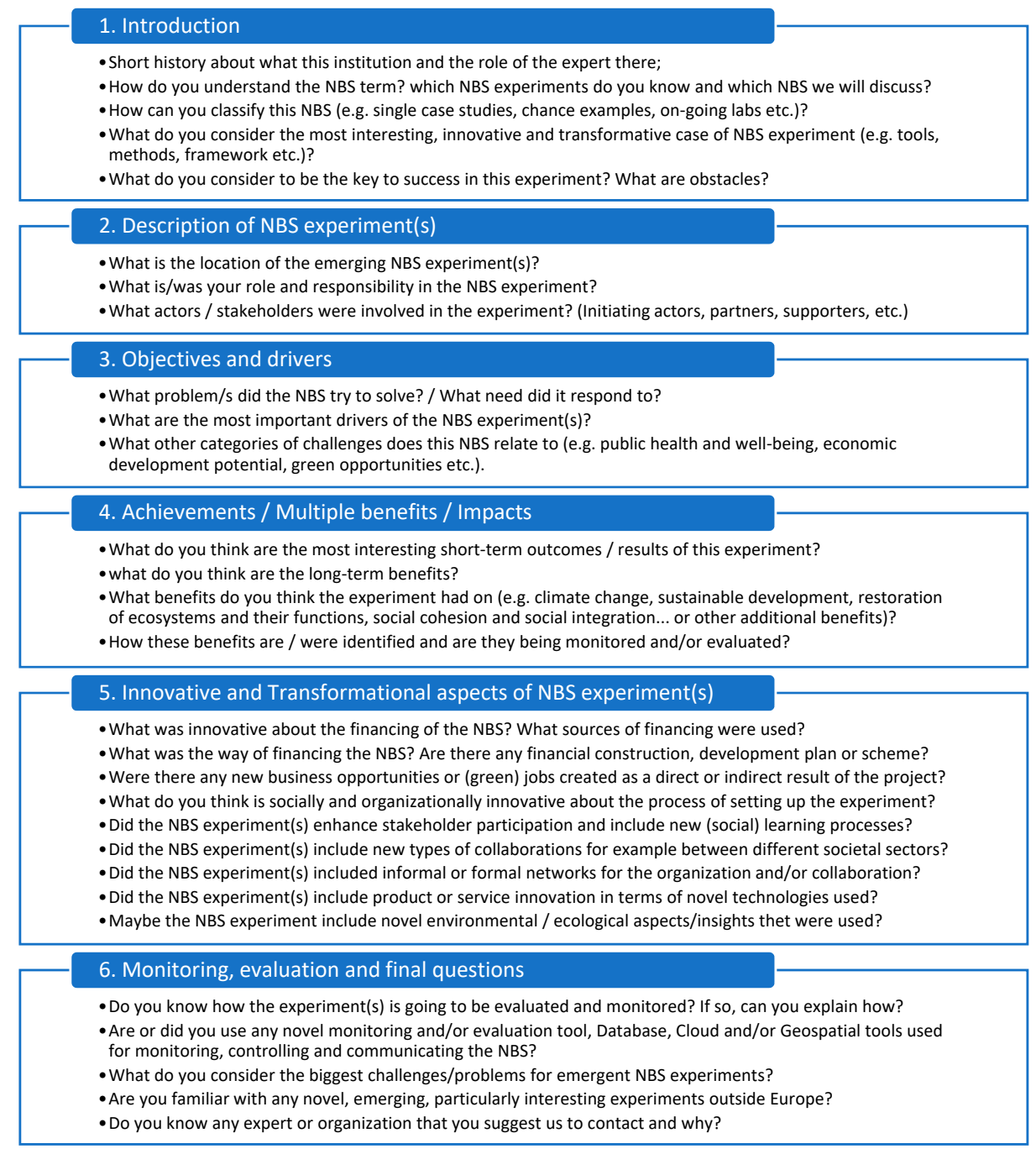

Figure 3. Interview template including the six-step iteration applied in the Leipzig study. 
Table 1. Classification of NBS interventions and selected cases from Leipzig referred to each category (based on [23-25], with own additions). Photos: D. Dushkova.

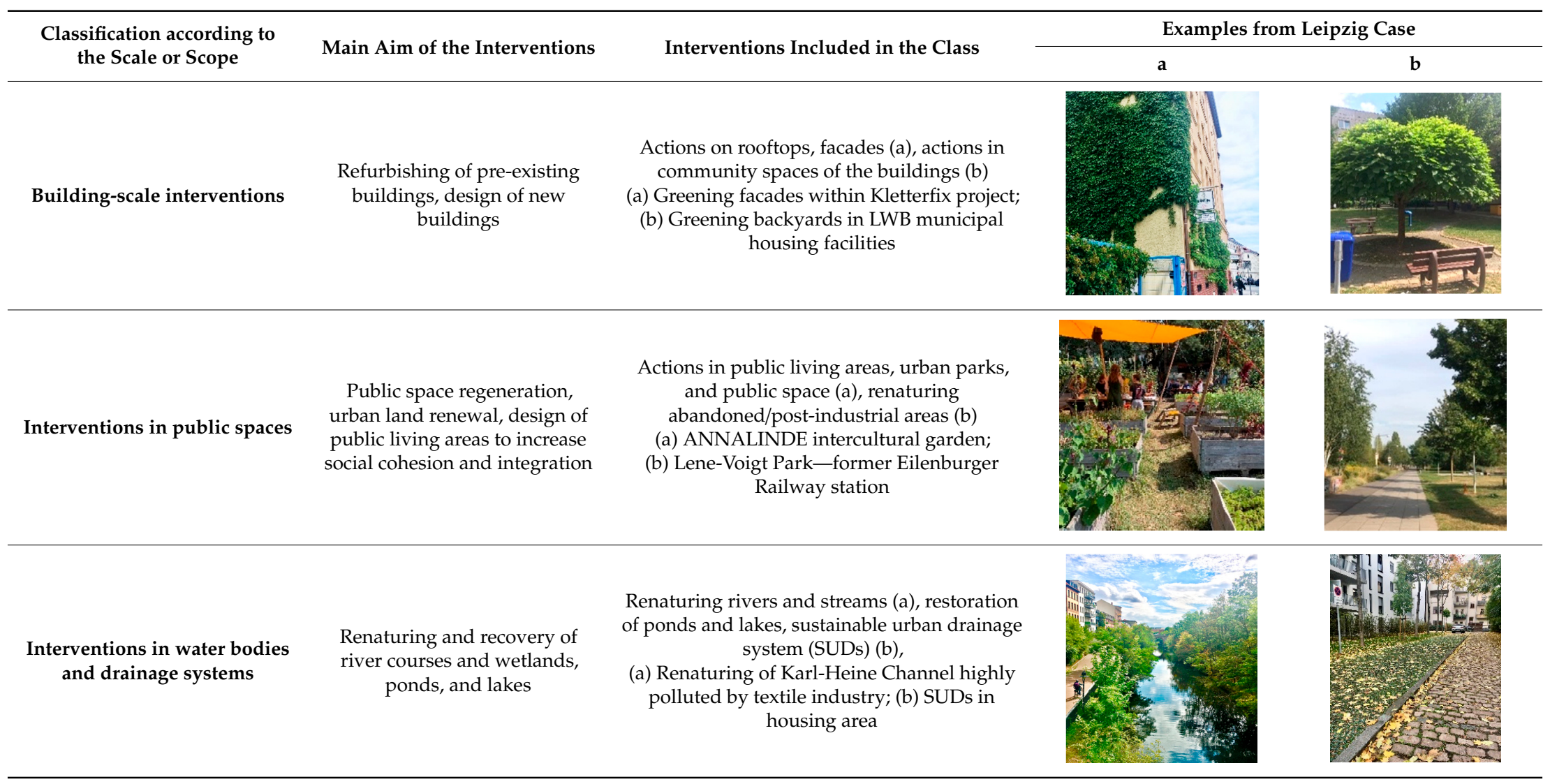


Table 1. Cont.

\begin{tabular}{|c|c|c|c|c|}
\hline \multirow{2}{*}{$\begin{array}{l}\text { Classification according to } \\
\text { the Scale or Scope }\end{array}$} & \multirow{2}{*}{ Main Aim of the Interventions } & \multirow{2}{*}{ Interventions Included in the Class } & \multicolumn{2}{|c|}{ Examples from Leipzig Case } \\
\hline & & & a & b \\
\hline $\begin{array}{l}\text { Interventions in linear } \\
\text { transport infrastructures }\end{array}$ & $\begin{array}{l}\text { Road projects, mobility plans, } \\
\text { redevelopment, } \\
\text { and greening streets }\end{array}$ & $\begin{array}{l}\text { Naturing actions for both high capacity (i.e., } \\
\text { roads-railways, etc. (a) and greening streets (b) } \\
\text { (a) Greening the tram railways; (b) City's tree } \\
\text { planting program: Baumstarke Stadt }\end{array}$ & & \\
\hline $\begin{array}{l}\text { Interventions in natural areas } \\
\text { and land management }\end{array}$ & $\begin{array}{l}\text { Master plans to use/manage } \\
\text { spaces, public space plans, } \\
\text { Green Infrastructure strategies, } \\
\text { agriculture, and forestry } \\
\text { promotion plans }\end{array}$ & $\begin{array}{l}\text { Natural protected areas, wetlands, peri-urban } \\
\text { parks, rural land management } \\
\text { (a) Leipziger Auenwald (Rosenthal park) } \\
\text { (b) Leipziger Neueseenland recreation spot } \\
\text { (former lignite mining area) }\end{array}$ & & \\
\hline $\begin{array}{l}\text { Ecological education and } \\
\text { awareness raising-related } \\
\text { interventions }\end{array}$ & $\begin{array}{c}\text { Awareness raising to } \\
\text { environmental issues, } \\
\text { stakeholders' and citizens' } \\
\text { involvement, knowledge } \\
\text { transfer }\end{array}$ & $\begin{array}{l}\text { Ecological festivals, workshops, master classes } \\
\text { (a) Umwelttage und Ökofete Leipzig } \\
\text { (b) Project "Edible city" and Nutrition } \\
\text { Council Leipzig }\end{array}$ & & \\
\hline
\end{tabular}


In total, 24 semi-structured interviews were conducted with municipal officers, stakeholders from nongovernmental organizations, private owners from SMEs, and citizens in the period between February 2018 and August 2019 (Appendix A, List of interviews). The interviews were mostly conducted in German and, after being transcribed, were translated into English. The interviews lasted between 29 and 128 minutes. The recording device used was an OLYMPUS digital voice recorder (WS-853). The interviews were transcribed with notes taken for the remainder and were analyzed using content and thematic analysis. Photographs and notes were taken during participant observation of events, excursions, and workshops. These were also used to hold informal talks with participants and interview partners.

The information was also obtained during the events:

- Annual “Eco-Festival” (Umwelttage Leipzig, 5-24 June 2018 and 5-16 June 2019)

- $\quad$ Annalinde Saison opening (13 April 2018)

- $\quad$ Spring festival of Annalinde intercultural garden (8 May 2019)

- Annalinde Herbal festival (24-25 August 2019)

- Guided open public excursion from the Project "Kletterfix" (19 June 2018)

- $\quad$ Guided excursions in Leipziger Neuseenland (23 June 2018 and 31 August 2019)

- Workshop “Edible City” (3 February 2018).

We also used secondary information that was collected at these events, in public information centers, and by researching web-based reports, published plans, and documentation distributed at public consultation events. We also used plans, newsletters, briefings, online information, and press articles as well as the web sites of the NBS interventions mentioned and analyzed in this paper. Some papers that addressed related issues were discussed during the site visits, workshops, and expert discussions that were focused on the potential of NBSs to address specific urban sustainability challenges in Leipzig.

\section{Results}

\subsection{History of Urban Greening and Implementation of NBS Interventions}

Before we analyze how the NBS concept is perceived in the city of Leipzig by different stakeholders and actors (city government, planners, private companies, nongovernmental organizations (NGOs), civil society, etc.), we provide here an overview of the history of urban greening and examples of prior so-called NBS innovations. In the case of Leipzig, these include pre-war cooperative and late-socialist housing developments that emphasized the need for planned green corridors and communal spaces.

The main core of green infrastructure in the city was developed during the socialist period, mainly in the 1950s and 1960s. For example, the centrally located Clara-Zetkin Park was shaped according to a Moscow blueprint [13]. Housing estates erected in the socialist era were planned with green spaces. These green spaces-which comprised backyards and courtyards-were designed to satisfy the requirements of the socialist society and were well equipped with roads, parking places, pedestrian walkways, waste collection sites, and also vast green spaces with children playgrounds and sport grounds (Figure 4).

Many of these spaces, which were also equipped with artworks and fountains, typified the architectural qualities of the modernism of the second half of the 20th century. The green urban concept of housing estates from this period responded to the socialist idea of the "collective dream". The playgrounds and landscape design of the backyards and courtyards in the housing estates can be perceived as prior NBSs since they contributed to human health and well-being, shaped the attractiveness of place, provided recreational and cultural value, fostered social cohesion, and created places for communication. After the fall of socialism and the reunification of Germany, a large part of such socialist estates in Leipzig-especially in its central and northern parts-has survived, even if, 
in some cases, their values have been lost as a result of the densification of housing, civic amenities, and parking spaces. Today, their fragments are still legible in the open spaces of housing estates.

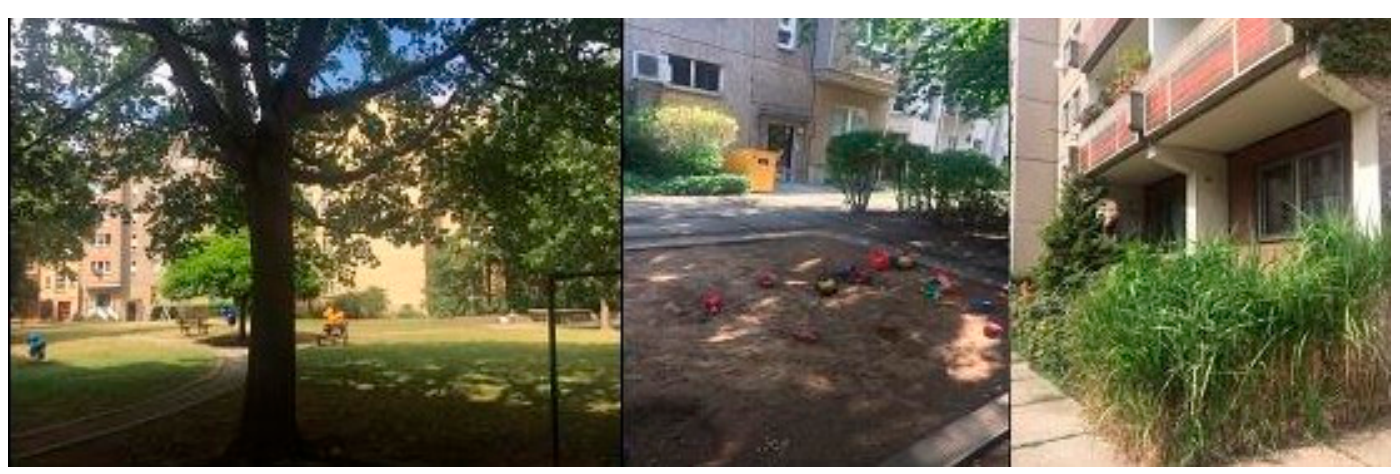

Figure 4. Greening the backyards and courtyards in socialist pre-fabricated housing estates of Leipzig Center as an essential element of socialist housing development and urban planning strategy. Photos: D. Dushkova.

As a consequence of intense industrial development, the negative environmental situation has been a crucial reason for out-migration from Leipzig since the 1960s, which shrank the city long before the political changes of the 1990s. Thus, from an environmental perspective, the post-socialist transformation offered a lot of relief, chances, and new opportunities for establishing novel nature-based solutions [13]. After 1990, a "green belt" around the city was created (Figure 5), which included the renaturation of former lignite coal mining sites as new water landscapes and also demanded active cooperation between urban and regional actors.

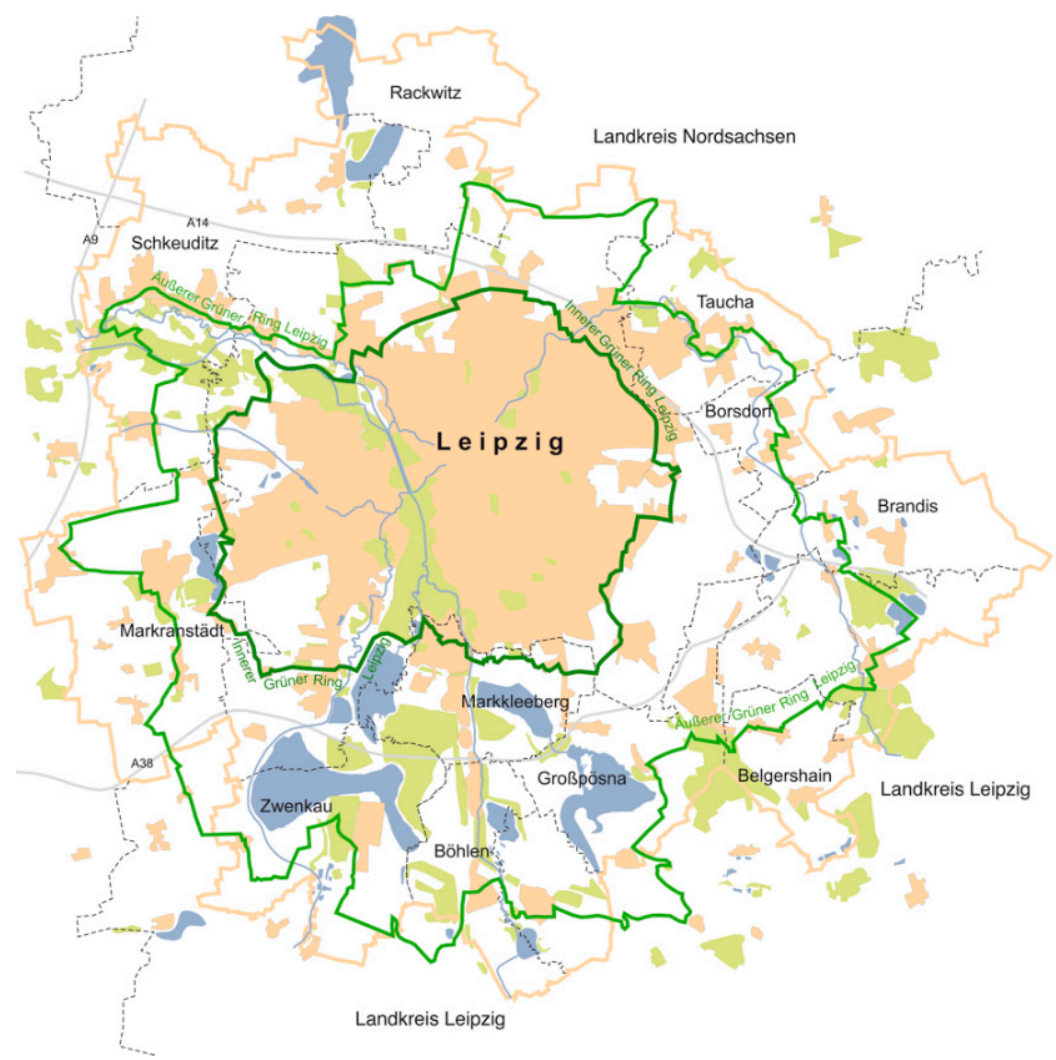

Figure 5. Green belt of Leipzig (dark green = 'Inner Green Belt'; light green = 'Outer Green Belt'). Source: Administrative Office of Green Ring Leipzig-https:/gruenerring-leipzig.de/wp-content/ uploads/2017/06/grünerring-kurzinhalt2.pdf. 
The Karl-Heine Channel was completely restructured and made accessible for walkers, cyclists, and boaters [26]. Urban community gardens, playgrounds, and urban agriculture experiments are widely popular in the city of Leipzig. Leipzig is also the origin of the long-allotment tradition that started in 1864 with the "Schreber movement". Later, through a movement born in England during the 1960s, community gardens became popular in Germany and introduced alternative methods such as permaculture into urban gardening (Figure 6). With its 270 allotment gardens, Leipzig now has the highest density of urban gardens in Germany. Besides such important ecosystem services as food provision (self-supply) and recreation, these gardens also play an important role by providing local climate regulation and biodiversity conservation [27].

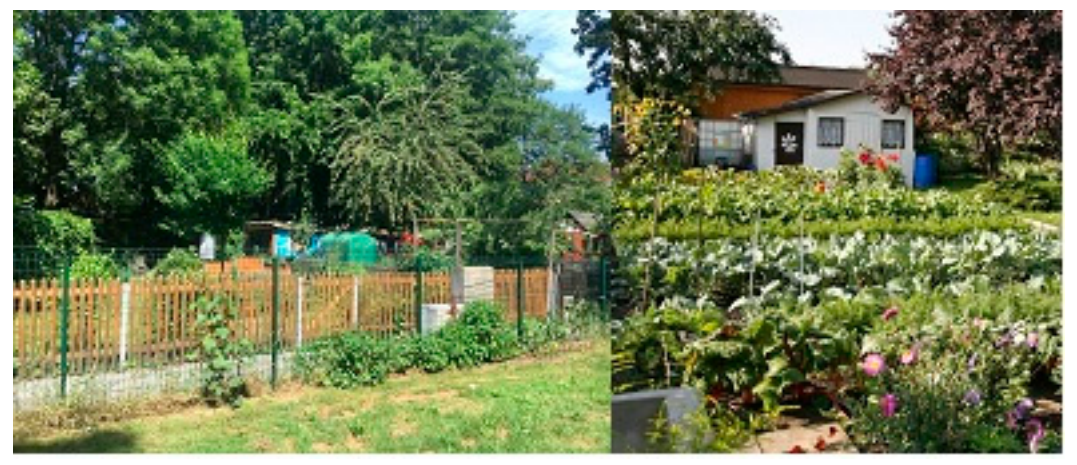

Figure 6. Allotment gardens of Leipzig-East. Photos: D. Dushkova.

Community gardens that contributed to the upswing of neighborhoods and attracted new inhabitants have to move constantly because of displacement. Traditional allotment gardens could also become endangered in the future by the demand for new building areas. At the moment, Leipzig finds itself in an interesting but complicated situation. The city benefits from a good image whereby green infrastructure plays an important role, but it is also under pressure because of new growth.

A novel concept of greening kindergarten areas within the NBS approach includes the nature-oriented playground for pre-school children that includes elements of nature alongside play equipment. These include sandy hills, live willow huts, and paths made from logs and stumps that are supplemented by green flowers, vegetable patches, herb beds, fruit bushes, and houses that allow children to grow their own plants or observe insects (Figure 7). By researching the incentivization of kindergartens in Leipzig, we discovered that a large number of developed and implemented projects de-sealed the concrete ground of playground areas by using native plants in the greening in order to enhance biodiversity with minimal maintenance. Designing the tree-based or meadow-like green spaces of kindergartens in this way can greatly contribute to adaptation to climate change, as air temperature is expected to decrease due to vegetation transpiration and canopy shade as well as due to de-sealing.

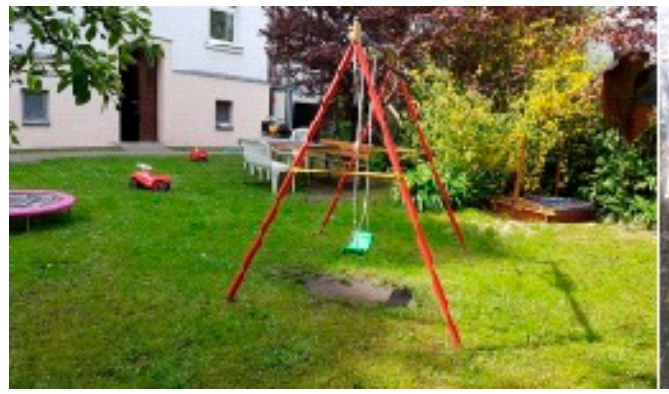

(a)

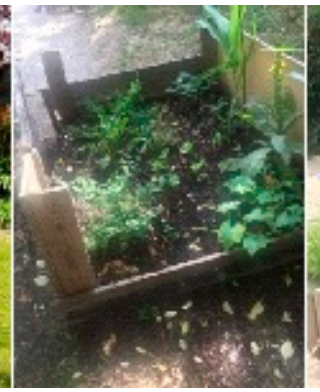

(b)

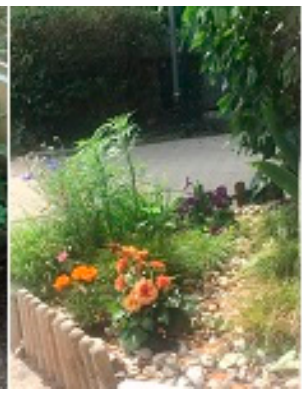

(c)

Figure 7. An innovative concept in greening areas near the kindergartens of Leipzig: (a) nature-oriented playground, (b) flower and vegetable beds, and (c) flower beds in water-sensitive design. Photos: D. Dushkova. 
NBSs such as the greening the open spaces of kindergartens are a part of the overall development concept of kindergartens in Leipzig. As such, the users of these areas may alter and create the conditions of their everyday activity areas in a self-determined way. "We organize the meetings with parents and children-users of our green spaces-in order to discuss the needs. Then, we can draw and even build miniature garden models in a box during the classes with our children. Such a participative approach excludes the hierarchies and is wonderful to hear and reflect every voice" (Interview \#20). In this sense, such newly created green areas of kindergartens can be defined as "play gardens" more than "playgrounds", giving children and their guardians the opportunity to experience nature directly and create an additional friendly greenspace in the city.

At the same time, solutions to the current social and environmental issues demand a set of tools and political will. Lene-Voigt Park, the Karl-Heine Channel, the Leipzig floodplains, and Leipzig New Lake Land are good examples of relevant problems and how greening cities can address them. These will be addressed in the following sections.

Under the conditions of climate change, it is crucial to protect and further develop the blue-green infrastructure network in Leipzig. In this context, NBSs can be responsible for the question of how activities should be improved in order to maintain important ecosystem services that are provided by the city's green and blue infrastructure. This will be discussed in the next sections of the paper.

\subsection{NBS Approach: Environmental Aspects in Urban Planning Policy Related to NBS}

In this section, we endeavor to answer two important questions: (1) Could many smart ideas that have been promoted in Leipzig (and described in the previous subsection as prior-NBS interventions) be included in and perceived as an NBS? (2) How is the NBS concept perceived in the city and by the city government, different stakeholders, and actors?

We find that the first question needs to be highlighted here in detail, since a great number of scientific debates and discussions with different stakeholders have revealed that the term is still unclear, and there is no precise differentiation between NBSs and prior interventions related to the environmental management, nature protection, greening measurements, etc. Nature conservation approaches and environment management initiatives have been carried out for decades and even for centuries as the case of Leipzig shows. What is new is that the multiple benefits of such NBSs to human well-being and society as a whole have been articulated well more recently. Even if the term itself is still being framed, examples of nature-based solutions can be found not only in Europe but also all over the world.

The concept of NBS itself was developed in order to propose a shift in nature conservation, environmental protection, and risk reduction from traditional 'hard' or 'gray' engineering solutions that exclusively involve structural features to 'softer', more eco-friendly solutions that simultaneously provide multiple benefits and are more cost-effective. In the last decades, a variety of new terms has started to be used to describe this type of solution, including the ecosystem-based approach, ecosystem services, green infrastructure etc. This variety of terms, coupled with a lack of specific details about the physical elements of the solution, can cause confusion. In our paper, we use the term nature-based solution (NBS) as the catch-all term for these approaches and according to the main stream of the CONNECTING Nature project, we are searching for innovative approaches by trying to identify what particular innovation can be found within particular NBSs to make it not just as a label but also a real tool to address the current societal challenges and achieve the sustainable development goals (www.undp.org).

As we learned from the work within the CONNECTING Nature project, one of the essential features that distinguishes NBSs from other environmental management-related interventions is using an innovation approach that brings together city governments, SMEs, academia, and civil society in order to co-produce usable and actionable knowledge, new business opportunities, and new governance models. By analyzing different NBS interventions presented in the database that we can 
name here, several innovations are coming through NBSs (presented in detail in the Appendix B for each NBS case):

- Improving the level of engagement of different actors participating in the development and implementation of NBSs (especially the business sector);

- Participation in decision making (public consultation, citizens budget);

- Inclusivity for multicultural society (e.g., a positive impact for as many social groups as possible);

- Accessibility to green and blue areas and providing environmental justice;

- Close collaboration between a wide range of stakeholders, which allows innovative problem solving and innovative organizational processes;

- Social and business innovations (innovations processes in organizational transformations (e.g., the people and structure of the organization have to be prepared for and capable of change);

- Fostering individual and collective innovative activity;

- Making use of innovative, interdisciplinary planning methods for green and blue space co-design and co-implementation, including the development of innovative social models for long-term positive management;

- Change in behaviors (awareness raising, promoting of eco-friendly lifestyle, etc.);

- Educational changes (workshops, events schools, pre-schools gardens, new gardens).

In order to answer the second question, we refer here to Cohen-Shacham et al. [24], who identified core principles for successfully implementing NBSs. Among these are synergy with other solutions, landscape-scale considerations, and policy integration. As the analysis of our NBS examples show, they can be implemented alone or in an integrated manner with other solutions. However, the successful cases should always be an integral part of the overall design of policies, measures, and actions taken to address societal challenges.

By discussing the features of current urban politics of Leipzig at the municipality level, we highlight the clear understanding that " ... the city became aware of needs to focus on the topic of greenery and nature. We support the programs and events which educate our citizens and decision makers even more about the economic and social values of urban greenery and nature-based solutions-from historical, botanical, and private gardens to parks, roadside and water-space greenery, greening façades and rooftops, and other outdoor spaces" (Interview \#18). As stated by the City Office (Department of City green and waters, Department of Environment protection), " . . partnerships and collaboration between different types of organizations and actors can produce previously unexpected solutions, especially when it comes to environmental issues" (Interview \#19). However, the problem is that members from different sectors of society often perceive NBS initiatives in different ways, pursuing their own interests. Thus, "... the current urban development strategy simply supports any kind of sustainable approaches somehow ... " (Interview \#19). This way, the city hopes to communicate and, subsequently, to harmonize the different ideas and visions regarding how to solve the social-environmental challenges on which this NBS paper is focuses.

The range of NBS initiatives in Leipzig "expands from preventing flooding to responding to heat island effects in big cities" (Interview \#19). The governance of those initiatives involves public authorities, the private sector, civil society, NGOs, the green movement, and academia. One such prominent example is the Leipzig Charter on Sustainable European Cities (Die Leipzig-Charta) [28]: the National Initiative for Urban Development Policy. This initiative aims to provide high-quality urban development in terms of design and planning that enables growth with low carbon emissions, thus improving environmental quality and reducing carbon emissions.

As our analysis shows, the first and still broadly used governance model of NBSs in Leipzig includes state involvement in financial management. The second model of NBS governance is volunteerism. A third model refers to those that were initiated by the private sector and in which the main stakeholders are businesses (SME). Nevertheless, one of the main points in the governance of NBS concerns the sharing of costs and risks between the private sector and the state. However, 
the involvement of business can be expensive and risky, and sometimes, it leads to different forms of social exclusion. It is common to encounter the mixed governance model of NBS where private and public sectors manage the finances together. Economic and social relations, as well as gentrification pressures, could become a significant challenge for the governance of NBSs. The key to successful NBS initiatives is the joint reflection of and by all the stakeholders [21].

In the case of Leipzig in the 1990s, many urban green initiatives were initiated and governed by public authorities and state actors. However, in the past few decades, the vision of the role of the public sector in greening initiatives in cities has started to change. At the moment, local public administrations still emerge as the main source of the overall vision, planning, and management of green infrastructure in cities. However, ". .. state actors attempt to work with society more as more people are involved in the green movement when the environmental issues have become more crucial" (Interview \#18). Public administrations organize public education courses and activities and try to work with volunteers through planting events. Adding more parks, trees, green roofs, green walls, playgrounds, and allowing for urban agriculture, green spaces, and gardens, as well as replacing hard surfaces such as parking lots with green spaces, were reported to be the main types of successful NBSs in the city. "The city administration is aware of the importance of its green and blue infrastructure for the city's economic development. We are welcoming new activities and pilot projects by providing financial incentives [and] supporting the cooperation with local stakeholders, local enterprises, and the various science and research institutes" (Interview \#18).

On the other hand, the idea of sharing opportunity costs and economic risks between the private sector and the state is not new, and it is certainly not unique to urban greening projects. Private sector and business should be involved in NBS projects, for example, in the context of shrinking state budgets and the long-term management of urban greening initiatives while benefits for the private sector fail with short-term interests [29]. Such arrangements are expected to deliver continuous economic growth, in the case of the EU, while avoiding irreversible and unpredictable changes to the global ecosystem [30].

Furthermore, state authorities and the private sector are not the only entities now actively involved in the governance of NBSs in Leipzig. Civil organizations and NGOs are also responsible for innovations and transitioning those green initiatives. They are seen as key actors for advocating for NBSs (providing applied evidence of their benefits) and re-establishing a green urban common [7]. As the case of Leipzig shows, " ... local residents and community groups very often positively perceive new NBS interventions in their neighborhoods if they respond to the needs to distribute socio-ecological benefits in order to reach ecological justice" (Interview \#18).

Engaging all actors in the process of implementing NBSs is a potential solution in which all sides benefit and where innovation, economic gains, biodiversity protection, and climate change could go hand in hand [7,31,32]. The partnering of different actors in the governance of NBS is perceived as " ... a way to reduce barriers/constraints to adopting NBS on a wider scale, which is especially important in terms of implementing NBS projects in cities" (Interview \#5).

The benefits of NBS only accrue when they are embedded in urban social-ecological systems-i.e., they need to reflect environmental conditions and needs, as well as socio-economic priorities, norms, and values, and human perceptions and institutional contexts that characterize specific local neighborhoods, the city as a whole, and regional connectivity $[8,33]$. While NBSs are often still initiated and financed by local governments, their long-term viability (e.g., through new business models) requires knowledge from multiple actors (e.g., citizens, NGOs, social innovation networks, businesses, and scientists) so that the solutions fit the needs and context of the city [32].

Today, a growing number of independent urban garden initiatives, intercultural community gardens, kindergartens, and school garden projects are revitalizing abandoned wasteland within the Leipzig city area. "These projects are extending the traditions of gardens as a place of communication, creation, and learning [while] contributing at the same time to the conservation of biodiversity in urban areas and shaping the healthy environment for their inhabitants" (Interview \#4). 
Maintenance and development plans (Pflege und Entwicklungspläne) play an important role, as they are an essential component of the overall green infrastructure site management developed by the city government. "... [T] hey have primarily been used to safeguard the quality of valuable sites such as protected areas, but in [the] future, they should also include green spaces" (Interview \#19). These maintenance and development plans integrate innovative approaches such as "protection through utilization" projects or "volunteer-based management interventions" which are organized, for example, by the city of Leipzig as part of the Leipzig Garden Programme (Interview \#4).

There are a number of current NBS projects that have been recognized as a novel collaborative mode of urban governance that use a mixed governance model based on co-creation and co-production. According to the European Union, these models are acknowledged as key mechanisms for dealing with sustainability challenges [34]. They allow for deep participation to leverage and weave together local, expert, and tacit knowledge and, ultimately, advance urban sustainability and resilience [3,7,8,32]. Co-creation and co-production promote collaborations and partnerships among diverse actors-including civil servants, citizens, planners, entrepreneurs, architects, scientists, and engineers-in the design, implementation, and eventual stewarding of NBS. As will be shown in the next sections of the paper, this mixed model has been successfully applied and works well in a variety of NBS examples.

\subsection{Analysis of NBS Examples}

In previous sections, we highlighted the urban challenge and how NBSs can meet them. We noted that the greatest benefits provided by NBSs include place making, air quality, urban heat mitigation, urban agriculture, acoustic control, storm water mitigation, biodiversity, aesthetic quality, human health and well-being, and social cohesion. In this section, we focus on the selected NBS examples that respond to the key sustainability challenges faced by the city of Leipzig (the NBS projects are listed in detail in Appendix B):

1. Greening façades (within the project Kletterfix)

2. ANNALINDE Intercultural Garden

3. ANNALINDE Urban Agriculture

4. ANNALINDE Academy

5. Project "Edible city"

6. Nutrition Council Leipzig

7. Lene-Voigt Park (renaturing a former industrial area to public green space)

8. Eco-food project from "Rosenberg Delikatessen"

9. Ecological festivals

10. City's tree-planting program

11. Leipziger Neuseenland (revitalization of post-mining area)

12. Karl-Heine Channel (revitalization of waterscape)

13. Leipziger Auwald (riverside/riparian forest)

These NBS examples represent the full range of NBSs by showing how social, economic, and environmental goals can be reached and which innovative approaches were implemented in order to provide a large variety of benefits such as climate change mitigation and adaptation, water management, quality of life, human health and well-being, attractiveness of place, social inclusion, and green job opportunities (Table 2). 
Table 2. Classification of the selected NBS examples in Leipzig. NGOs: nongovernmental organizations.

\begin{tabular}{|c|c|c|c|c|c|c|}
\hline NBS Case & Time Frame & Motivation & Initiator/Stakeholders & Benefits & Source of Financing & Project Budget \\
\hline $\begin{array}{l}\text { 1. Green facades and } \\
\text { walls for } \\
\text { Leipzig-Kletterfix }\end{array}$ & 2015-ongoing & $\begin{array}{l}\text { to create and raise awareness about the } \\
\text { multiple benefits of urban green and inspire } \\
\text { the action of tenants and landlords on } \\
\text { private property }\end{array}$ & $\begin{array}{l}\text { NGO Ökolöwe/City } \\
\text { Leipzig }\end{array}$ & $\begin{array}{l}\text { improvement of urban microclimate and } \\
\text { general living conditions, increase urban } \\
\text { biodiversity, combat particulate matter } \\
\text { pollution, generate economic savings } \\
\text { for tenants }\end{array}$ & $\begin{array}{l}\text { public local } \\
\text { authority's budget, } \\
\text { funds of NGOs }\end{array}$ & $\begin{array}{c}\text { less than } 50,000 \\
\text { EUR }\end{array}$ \\
\hline $\begin{array}{l}\text { 2. ANNALINDE } \\
\text { Interkultural Garden }\end{array}$ & 2011-ongoing & $\begin{array}{l}\text { to create places of exchange and learning on } \\
\text { ecological growing of food, biodiversity, } \\
\text { sustainable consumption, responsibility in } \\
\text { resources, sustainable neighborhoodd, } \\
\text { and urban development }\end{array}$ & \multirow{3}{*}{$\begin{array}{c}\text { civil society-neighbors } \\
\text { and volunteers, } \\
\text { NGO/civil society, } \\
\text { citizens or community } \\
\text { groups, ANNA-LINDE } \\
\text { GmbH }\end{array}$} & $\begin{array}{l}\text { public space regeneration, urban land } \\
\text { renewal, and design of public living areas to } \\
\text { increase social cohesion and integration, }\end{array}$ & \multirow{3}{*}{$\begin{array}{l}\text { EU funds, public } \\
\text { national budget, } \\
\text { public local } \\
\text { authority's budget, } \\
\text { funds provided by } \\
\text { NGOs, } \\
\text { crowdsourcing }\end{array}$} & \multirow{3}{*}{ n.a. } \\
\hline $\begin{array}{l}\text { 3. ANNALINDE } \\
\text { Urban agriculture }\end{array}$ & 2011-ongoing & $\begin{array}{l}\text { to encourage, reactivate urban gardening, } \\
\text { cultivate vegetables according to the } \\
\text { standards of organic farming, to provide } \\
\text { social interaction and mutual learning }\end{array}$ & & $\begin{array}{l}\text { gardens on unbuilt areas open to all and for } \\
\text { active engagement with social issues }\end{array}$ & & \\
\hline $\begin{array}{l}\text { 4. ANNALINDE } \\
\text { academy }\end{array}$ & 2011—ongoing & $\begin{array}{l}\text { environmental awareness rising, knowledge } \\
\text { transfer, stakeholders' and citizens' } \\
\text { involvement through master classes, } \\
\text { workshops in urban agriculture, gardening, } \\
\text { recycling, composting }\end{array}$ & & $\begin{array}{l}\text { opportunities for joint and experience-based } \\
\text { learning toward urban resilience and } \\
\text { sustainable development, shaping } \\
\text { environmental culture, contributing to } \\
\text { sustainable urban living }\end{array}$ & & \\
\hline 5. "Edible city" & 2018-ongoing & $\begin{array}{l}\text { to promote edible species within public } \\
\text { spaces (parks, pedestrian streets, etc.) as a } \\
\text { source of food with financial advantages for } \\
\text { municipality and citizens, environmental } \\
\text { awareness rising, knowledge transfer, } \\
\text { stakeholders' and citizens' involvement }\end{array}$ & $\begin{array}{l}\text { NGOs, civil society } \\
\text { groups }\end{array}$ & $\begin{array}{l}\text { good peri-urban relationships, sustainable } \\
\text { regional agriculture, local food production, } \\
\text { support of local food producers, gardening } \\
\text { movement aiming to turn the city into an } \\
\text { edible garden }\end{array}$ & $\begin{array}{l}\text { NGO funds, civil } \\
\text { society groups funds }\end{array}$ & n.a. \\
\hline $\begin{array}{l}\text { 6. "Nutrition Counsil } \\
\text { Leipzig" }\end{array}$ & 2019_ongoing & $\begin{array}{l}\text { to improve the food system in Leipzig and } \\
\text { make it more ecological and more } \\
\text { democratic; to ensure the long-term } \\
\text { sustainable supply of the city's population } \\
\text { with regional, seasonal, and healthy food }\end{array}$ & $\begin{array}{l}\text { civil society groups, } \\
\text { farmers, processors, } \\
\text { retailers, restaurateurs, } \\
\text { municipality } \\
\text { representatives }\end{array}$ & $\begin{array}{l}\text { better dialogue between different actors of } \\
\text { food system in the city; the development of } \\
\text { a sustainable regional agricultural system, } \\
\text { biodiversity conservation; knowledge and } \\
\text { education platform about the production, } \\
\text { marketing, and the supply of the food in } \\
\text { the region }\end{array}$ & $\begin{array}{l}\text { civil society groups } \\
\text { funds, private } \\
\text { companies, } \\
\text { municipality }\end{array}$ & n.a. \\
\hline 7. Lene Voigt Park & 2001-2004 & $\begin{array}{l}\text { to renaturate a former industrial area to } \\
\text { public green space, to connect eastern } \\
\text { districts and the 'green lungs' of the city } \\
\text { (park as a part of a green belt), to co-create } \\
\text { with residents (through workshops), to offer } \\
\text { more green space for the dense housing area }\end{array}$ & City of Leipzig & $\begin{array}{l}\text { to initiate residential change of the } \\
\text { surrounding areas and the development of } \\
\text { the local urban infrastructure, e.g., cafes, } \\
\text { shops. New residents moved there and } \\
\text { housing vacancies started to decrease }\end{array}$ & City of Leipzig & n.a. \\
\hline
\end{tabular}


Table 2. Cont

\begin{tabular}{|c|c|c|c|c|c|c|}
\hline NBS Case & Time Frame & Motivation & Initiator/Stakeholders & Benefits & Source of Financing & Project Budget \\
\hline $\begin{array}{l}\text { 8. Eco-food project } \\
\text { "Rosenberg } \\
\text { Delikates-sen" }\end{array}$ & 2016-ongoing & $\begin{array}{l}\text { to establish green business/company, to use } \\
\text { regional food/products, to support regional } \\
\text { fluxes of materials and energy balance }\end{array}$ & private initiative & $\begin{array}{l}\text { respect to traditional } \\
\text { processing/manufacturing of regional fruits, } \\
\text { good networking that involves different } \\
\text { actors, the promotion of regional agriculture } \\
\text { and products }\end{array}$ & private initiative & n.a. \\
\hline $\begin{array}{l}\text { 9. Ecological festivals } \\
\text { (Umwelttage and } \\
\text { Ökofete) }\end{array}$ & 1990-ongoing & $\begin{array}{c}\text { awareness raising on environmental issues, } \\
\text { knowledge transfer, stakeholders' and } \\
\text { citizens' involvement }\end{array}$ & $\begin{array}{l}\text { NGO funds, City of } \\
\text { Leipzig, private } \\
\text { companies, etc. }\end{array}$ & $\begin{array}{l}\text { environmental education, active } \\
\text { engagement of citizens in the city greening } \\
\text { and environmental activities }\end{array}$ & $\begin{array}{l}\text { NGO funds, City of } \\
\text { Leipzig, private } \\
\text { companies, etc. }\end{array}$ & n.a. \\
\hline $\begin{array}{l}\text { 10. City's tree planting } \\
\text { program (Baumstarke } \\
\text { Stadt) }\end{array}$ & 1996-ongoing & $\begin{array}{l}\text { to give private people and businesses the } \\
\text { opportunity to donate money for the } \\
\text { planting of one or more trees, active } \\
\text { engagement of citizens in the city greening }\end{array}$ & $\begin{array}{l}\text { City of Leipzig, citizens, } \\
\text { and private companies }\end{array}$ & $\begin{array}{l}\text { city greening, place attractiveness, air } \\
\text { quality, promoting the special cultural } \\
\text { meanings that many attach to trees, i.e., as a } \\
\text { source/giver of life or a memory site or } \\
\text { symbol, financial contribution of citizens to } \\
\text { the city greening }\end{array}$ & $\begin{array}{l}\text { public local } \\
\text { authority's budget, } \\
\text { corporate investment, } \\
\text { crowdsourcing }\end{array}$ & $\begin{array}{l}\text { n.a. (tree } \\
\text { sponsorships of } \\
250 \text { EUR and } \\
\text { more pro one } \\
\text { tree) }\end{array}$ \\
\hline $\begin{array}{l}\text { 11. Leipziger } \\
\text { Neuseenland (Leipzig } \\
\text { new lakes regions) }\end{array}$ & 1994_ongoing & $\begin{array}{l}\text { to create a new peri-urban landscape } \\
\text { through revitalization of the post-mining } \\
\text { landscape destroyed by vast open lignite } \\
\text { mines (remaining craters are renaturalized } \\
\text { and flooded with ground or rainwater to be } \\
\text { revived as recreational lakes) }\end{array}$ & $\begin{array}{l}\text { mining companies, } \\
\text { scientific institutions, } \\
\text { recreational business, } \\
\text { regional and national } \\
\text { bodies }\end{array}$ & $\begin{array}{l}\text { renovation and development of a new } \\
\text { concept for the former mines, including the } \\
\text { creation of new employment opportunities, } \\
\text { improvements in environmental conditions } \\
\text { (air and water quality), recreational area }\end{array}$ & $\begin{array}{l}\text { public national } \\
\text { budget, public } \\
\text { regional budget, } \\
\text { corporate investment }\end{array}$ & $\begin{array}{c}\text { above } 4,000,000 \\
\text { EUR }\end{array}$ \\
\hline $\begin{array}{l}\text { 12. Karl-Heine } \\
\text { Channel }\end{array}$ & 2005-onging & $\begin{array}{l}\text { to renaturate and recover the river courses } \\
\text { and wetlands, ponds, and lakes, sustainable } \\
\text { redevelopment of the post-mining area into } \\
\text { forestry and recreational areas and } \\
\text { reintegrate it into the adjacent landscape }\end{array}$ & $\begin{array}{l}\text { City of Leipzig, external } \\
\text { experts, Forum for } \\
\text { Leipzig West (business, } \\
\text { NGOs, citizens) }\end{array}$ & $\begin{array}{l}\text { installing waterside greenery, developing } \\
\text { the green zones of former waterside } \\
\text { embankments to interlink green areas in the } \\
\text { whole city, a cycle path network along the } \\
\text { canal, recreational areas, attractiveness of } \\
\text { space, human well-being }\end{array}$ & $\begin{array}{l}\text { City of Leipzig, } \\
\text { national funds, EU } \\
\text { funding }\end{array}$ & 5,500,000 EUR \\
\hline $\begin{array}{l}\text { 13. Leipziger Auwald } \\
\text { (Riverside/Riparian } \\
\text { forest) }\end{array}$ & 1991-2011 & $\begin{array}{l}\text { environmental protection strategy and } \\
\text { master plans to use/manage spaces, public } \\
\text { space plans, Green Infrastructure strategies }\end{array}$ & $\begin{array}{l}\text { Leipzig University, } \\
\text { UFZ, iDiv, } \\
\text { Naturkundemuseum, } \\
\text { City of Leipzig, NGOs } \\
\text { (Ökolöwe, NABU, etc.) }\end{array}$ & $\begin{array}{c}\text { biodiversity conservation, air cooling, } \\
\text { shading and transpiration, flood mitigation, } \\
\text { carbon storage, habitat provision, legislation } \\
\text { (nature reserve); workshops to promote the } \\
\text { value of Auwald, awareness raising } \\
\text { (cultural open-air events and concerts), } \\
\text { recreation }\end{array}$ & $\begin{array}{l}\text { public local } \\
\text { authority's budget, } \\
\text { funds provided by } \\
\text { NGOs, etc. }\end{array}$ & $\begin{array}{l}\text { n.a. (partly } \\
\text { municipality } \\
\text { 198,000 Euro }\end{array}$ \\
\hline
\end{tabular}




\section{Discussion}

\subsection{Factors of Success of NBS Examples}

The following aspects that contribute to the successful existence of selected NBS examples were discovered by looking at the history of their creation, their impact (environmental, social, and economic), governance models (initiator, stakeholders, beneficiaries), methods of implementation, design, and maintenance, and additional benefits, costs, and financing:

- Multifunctional in the best sense, having a wide spectrum of ecological and social activities and multiple benefits

- "Formalize the NBS"-political support and willingness (close collaboration with municipality: implementation of projects into the master planning of a city and municipality programs, regular dialogue with urban policy makers and planners to facilitate knowledge transfer, strong local commitment to protect implementation)

- Community engagement in the design and implementation process-a high degree of citizen participation and "accessibility" of the NBS

- Close collaboration between a wide range of stakeholders that allowed innovative problem solving

- Participatory processes that support stakeholder empowerment

- Locally grown solutions (e.g., a preference for using elements of traditional nature-based practices more than approaches that rely on bringing "new" interventions in from the outside)

- Secured financing for a longer period

- Outcomes of the NBS are clearly communicated, accessible, and attractive in regarding their benefits (environmental, economic, for health and well-being, joy, aesthetics, etc.) for local residents

As we see from all the selected NBS examples, at the local level, an NBS strategy (development) first requires the active consideration and combination of the above approaches to address sustainable development goals (SDGs) [35], especially when aiming to reduce climate risk on the ground. For example, among these SDGs are SDG3 (good health and well-being), SDG 11 (sustainable cities and societies), and SDG12 (responsible consumption and production). Second, to ensure their sustainability, NBS strategies must be implemented at the local, institutional, and inter-institutional levels. Third, the different measures and strategies only lead to sustainable change when combined. Finally, other cross-cutting issues (notably climate change mitigation) can create synergies and support progress.

By analyzing different NBS cases, we can state that the same NBSs may have a different impact in different local contexts. As our analysis shows, expensive greening and revitalization projects (e.g., Neuseenland) on former brownfield or post-industrial sites, for example, work only in contexts where the resulting costs can be paid by state and/or private actors. Projects related to urban gardening (e.g., ANNALINDE urban gardening and intercultural garden) may be successful, given the presence of a motivated and active local community, but will fail if there is apathy and disinterest or even a conflict of interests. The majority of selected NBS examples are largely initiated by citizens and with a strong presence of civil society groups in their creation, implementation, and maintenance. Considering the context in which NBSs are implemented is of great importance for political and power structures, ways of making decisions, and the inclusion of certain groups of inhabitants and/or actors.

As was pointed out in the interviews, factors that lead to success include state-driven initiatives that are supported by private companies and focus on enhancing the attractiveness of the area, providing new recreation facilities, and generating economic growth and employment through tourism (as in case of New Lake Land). Federal support for ecological revitalization was also one of the key drivers for the Karl-Heine Channel project, which aimed to harmonize living conditions during ecological transition as a part of welfare policy. However, as emphasized by several interview experts, federal funds would not be enough without the active participation of civil society. In order for this participation to occur, awareness of the importance of particular ecosystems and their functions is essential (ANNALINDE Academy, Ecofestivals). For example, in Leipzig, the creation of awareness 
of the floodplain and its related ecosystem services to both people and nature was a key driver of success. For the most part, a combination of different factors was responsible for the success of the NBS example. These included the continuous development of innovative strategies to produce healthy local food, respect for traditional farming of regional fruits and vegetables, effective networking that involves different actors (Rosenberg Delikatessen), co-creation with residents (through workshops), and the provision of more green space for dense housing areas, thus leading to an increase in the attractiveness of places and districts (Lene-Voigt Park).

\subsection{Impact of NBS Examples on the Environment, Economics, Society, and the Sustainable Development of the City}

In response to the research questions, several options can be outlined that utilize the functionality of NBSs to better face current societal challenges, especially the consequences of climate change in cities and urban regions. The following are the key observations:

- Only the right green projects in the right place (e.g., environmentally based, proven, and responding to the current needs of urban society) can have a positive and long-term effect.

- As our results show, NBSs have a far greater environmental, economic, and social value than generally assumed.

- Investing in restoring, protecting, and enhancing ecological functionality and ecosystem services through the implementation of different NBSs is not only ecologically and socially desirable $[16,17,31]$, but also, as the contribution has shown, the multiple benefits obtained from NBSs have a great value for a large number of beneficiaries in the city of Leipzig.

The impacts of the selected NBS examples are presented in Table 3.

Table 3. Impact of NBS examples for environment, economics, society, and the sustainable development of Leipzig.

\begin{tabular}{|c|c|c|}
\hline Social Value of NBS & Economic Value of NBS & Ecological Value of NBS \\
\hline $\begin{array}{l}\text { creating safe and welcoming } \\
\text { spaces for residents, leisure } \\
\text { and recreation with associated } \\
\text { therapeutic values }\end{array}$ & $\begin{array}{l}\text { improvements in residential quality and } \\
\text { image of the area (through further } \\
\text { upgrades to existing or creation of new } \\
\text { green spaces), which contributes to its } \\
\text { attractiveness for potential investors and } \\
\text { new residents }\end{array}$ & $\begin{array}{l}\text { climate change mitigation and adaptation } \\
\text { (flood mitigation through local water } \\
\text { retention and revitalization of water } \\
\text { landscapes; heat and drought mitigation); } \\
\text { microclimate improvements through raising } \\
\text { the number and quality of green spaces }\end{array}$ \\
\hline $\begin{array}{l}\text { promoting integration and } \\
\text { social cohesion }\end{array}$ & $\begin{array}{l}\text { mobilization of private and public } \\
\text { finances for the upgrading of structurally } \\
\text { disadvantaged areas }\end{array}$ & $\begin{array}{l}\text { biodiversity conservation and } \\
\text { habitat provision }\end{array}$ \\
\hline $\begin{array}{l}\text { contribution to interaction } \\
\text { between diverse ethnic and } \\
\text { social groups, also with } \\
\text { migration background }\end{array}$ & $\begin{array}{l}\text { green job opportunities through the } \\
\text { creation of green business models of NBSs }\end{array}$ & $\begin{array}{c}\text { decrease in air pollution (including lower } \\
\text { emission rates through promoting } \\
\text { green mobility) }\end{array}$ \\
\hline $\begin{array}{l}\text { providing opportunities for } \\
\text { active engagement }\end{array}$ & $\begin{array}{l}\text { financial incentives when } \\
\text { implementing NBSs }\end{array}$ & regeneration of derelict areas \\
\hline $\begin{array}{l}\text { raising a district's cultural } \\
\text { vitality and image, thus } \\
\text { contributing to the } \\
\text { attractiveness of place }\end{array}$ & $\begin{array}{l}\text { better infrastructure through the } \\
\text { provision of safe pedestrian and cycle } \\
\text { paths to connect different parts of the city }\end{array}$ & reduced land usage \\
\hline $\begin{array}{c}\text { enhancing public perception of } \\
\text { the area }\end{array}$ & $\begin{array}{l}\text { extension of the touristic infrastructure } \\
\text { and better connection to transregional } \\
\text { tourism networks }\end{array}$ & $\begin{array}{l}\text { sustainable living (through responsible } \\
\text { consumption and production, increased } \\
\text { resource efficiency, etc.) }\end{array}$ \\
\hline
\end{tabular}

During the analysis, we found the follow types of NBS interventions in Leipzig:

- Type 1: NBSs that involve making better use of existing natural or protected ecosystems (e.g., measures to increase ecosystem services supply)—the Karl-Heine Channel, Leipziger Auwald

- Type 2: NBSs based on developing sustainable management protocols and procedures for managed or restored ecosystems (e.g., re-establishing traditional agro or forestry systems, etc.)—Baumstarke Stadt, Leipziger Auwald, Nutritution Counsil, and Edible City 
- Type 3: NBSs that involve creating new ecosystems from existing abandoned, brownfields, or neglected area (e.g., establishing green buildings, green walls, green roofs)—Lene-Voigt Park, Neuseenland, and ANNALINDE intercultural garden

- Type 4: NBSs that involve creating new ecosystems (e.g., establishing green buildings, green walls, green roofs)—Kletterfix project

- Type 5: NBSs that aim for responsible consumption and production based on generating awareness, ecological education, and sustainable actions-ANNALINDE Academy, Rosenberg Delikatessen, Ecofestivals.

\subsection{Limitatations Associated with Trade-Offs and Conflicts around the NBS}

The implementation of effective and durable NBSs face potential barriers, as identified by $[7,8,21]$. They include "strong stakeholders" or private business (such as housing associations, investors, or developers) with whom a city or municipality has to enter into contractual obligations. Another associated barrier is the risk of "overselling nature" $[9,36]$ or encouraging a perception of ecosystems as entirely substitutable by other assets used by humans. In addition, financial limitations can occur, leading to the inadequate development and maintenance of NBSs (e.g., financial stress, changes in funding priorities within a new political cycle, other barriers in financial mechanisms). In addition, insufficient incentives and regulations to encourage the private sector to include NBSs in developments may hinder the implementation process of NBSs. For instance, the private sector often lacks incentives that would make the business cases for the NBS better defined and attractive.

As we learned from the CONNECTING Nature project discussions and interviews with different stakeholders, many positive effects are not taken into account when implementing NBSs, such as social impacts, which simply cannot be monetarized. The scientific community still experiences a lack of tools or methods to describe the positive effects of NBS, which require a unified methodology and framework for the assessment and evaluation of NBSs. There are still gaps and barriers in the impact assessments of NBSs-in most of the NBS projects, the long-term monitoring of the impact of NBSs is not foreseen; however, it would be an essential part of promoting the NBS concept and approach.

As stated by variety of stakeholders, the long-term benefits are not clearly defined for them and for citizens, which pose an additional task for the city to visualize the effects of projects regarding the long-term benefits $[7,9,11,13,17,19,37]$. As our previous research shows, very few trade-offs were identified so far, such as eco-gentrification, ecosystem disservices, etc. [7,13,37].

Coming back to our case of Leipzig, we reveal the following actions, which were developed and introduced by a variety of different actors in order to overcome these limitations:

- Development of shared visions (as we noted by different NBS cases presented in the Appendix B such as Nutrition Council, ANNALINDE Academy, etc.).

- Implementation of environmental and sustainability management systems (Leipzig has developed and introduced different strategies such as the Leipzig Charter on Sustainable European Cities, the Leipzig Garden program, maintenance and development plans, the city's tree planting program, ecological festivals etc., which highlight the embedding of NBSs in existing plans and strategies).

- Different campaigns to raise awareness for different stakeholders, including citizens (such as Edible Cities, Nutrition Council, Ecological festivals, etc.).

- Supporting formal and informal networks between different actors involved in the creation and implementation of NBS (for further details, please see the Appendix B).

- $\quad$ Supporting public-private partnership (for further details, please see the Appendix B).

- Use financial incentives and compensation schemes (e.g., when implementing green walls, as shown by the Kletterfix project).

In addition, powerful socio-economic interests can dominate greening initiatives and be placed above other social equity needs or priorities [37]. For instance, this could involve the generation of economic value from deprived locations through the redesign of parks and the capture of a rent gap, 
which can in turn cause gentrification - possible trade-offs of greening projects—in $[16,17,29]$. This can be illustrated by the current situation in Lene-Voigt Park, which has been redesigned following a growth-oriented strategy that involved targeting the rising attractiveness of nearby housing estates and neighborhoods. This caused rents to rise and poses the risk of displacement for vulnerable social groups, e.g., low-income households and migrants.

Another barrier can arise because of short-term subcontracting to non-profit and private actors for the management of green spaces, which is a practice that is currently actively used in Leipzig. On the one hand, as a positive outcome, the neglected or abandoned areas are managed through public budgets and as a public responsibility, which helps the city to save scarce municipal funds. On the other hand, it can result in transforming the green area into a market-based and a quasi-private space $[21,29]$.

As we have learned, local residents and community groups might either welcome or contest NBS interventions in their neighborhoods, depending on how the interventions (re)distribute socio-ecological benefits. In this regard, the issue of justice in the distribution of benefits and power-between genders as well as ethnic and cultural groups-can arise. Therefore, existing research on environmental justice in cities provides a distinct pathway toward-and source of data and analysis on-inequities produced by urban greening initiatives and strategies [37,38]. In addition, [39] conclude that access to green space is still highly stratified according to income, race, ethnicity, age, gender, (dis)abilities, and various other axes of difference. As concluded by [37], if green or natural areas do not meet the culturally and socially defined needs of potential visitors, the authors conclude that they may be used less frequently or be less effective for recreation. Recently, much research has addressed the process of making older urban areas inhabited by the lower-income population more livable and attractive with greening projects. The resulting processes have been termed ecological-, green-, environmental-, or eco-gentrification [40-43].

In our previous research $[11,13,22]$, we concluded that even when NBSs are expected to contribute to the overall improvement of the living and health standards of urban citizens, the trade-offs that have resulted from several NBS interventions can be connected with a number of unexpected and undesired issues. For instance, urban greening might not automatically provide social and environmental sustainability in cities when we consider maintenance costs resulting from dry summers and the need to invest additional money, as we learned from the case of Lene-Voigt Park or the concept of the Tree-City (Baumstarke Stadt). Another dimension of justice in the planning and management of greening projects in urban areas is the sense of community and refuge that certain types of natural areas in cities tend to provide. The improved environmental conditions are often related to emotional needs and the search for community, belonging, protection, and safe spaces [40]. This emotional need reflects the importance of providing intangible values for some individuals such as place attachment or place of belonging, for example, through social urban gardens (e.g., ANNALINDE projects).

\section{Conclusions}

In summary, there is a broad spectrum of NBS types present in Leipzig that includes the creation of wildness patches and recreational areas in former mining landscapes and central parts of the city, the renaturation of rivers (especially those that were highly polluted during the time of industrialization), and the creation of urban green and blue infrastructure that is interconnected by cycling pathways (green roads, green walls, etc.) in order to connect the green and blue spaces of the city center with those in the suburban areas. Along with these NBS interventions, which are mostly initiated and supported by the government, many different initiatives have occurred or appeared in which the main initiators and drivers are citizens and NGOs (intercultural and neighborhood gardens, projects aiming to create awareness of environmental issues, awareness raising, and citizen involvement, etc.). They all addressed the issues of urban regeneration, coping with former industrial and neglected areas (e.g., brownfields), demanding green space for several urban districts that are currently referred to as the biggest challenges for several cities in Europe and beyond. 
The idea of NBSs is now increasingly being implemented in finding a solution for biodiversity loss, climate change, the sustainable use of natural resources, and air pollution together with public health, social justice, and green economic opportunities in the cities. In the era of urbanization-and its associated sustainability challenges and business opportunities for those involved in the construction sector and urban planning-the concept of NBSs turns out to be highly topical.

Most of the NBS examples analyzed in this paper are valued recreational areas. They provide many benefits for urban dwellers such as fresh air, moisture, oxygen, and biogenic essentials as well as many cultural and place-based values. They are very efficient spaces for climate change mitigation, water and matter regulation, pollutants fixation, and flood water retention [16,17]. Thus, they represent perfect nature-based solutions for almost all current sustainable developments goals, particularly in the case of dense urban areas of Leipzig. These goals include risk mitigation and adaptation to the effects of climate extremes such as flood and drought, the disruption of food provision, social justice, and more. Moreover, they can serve as a buffer against high air temperatures and provide moisture during heatwaves. However, urban wetlands and riparian forests are often endangered by different land-use conflicts that have resulted from urbanization pressure such as land take for construction purposes and pollution. This paper has argued that urban NBSs now present a great opportunity with multiple benefits for a great number of beneficiaries in cities that are facing the effects of climate change. Further, we argue that NBSs present design options for expanding existing and even creating innovative new tools for sustainable development policy.

However, we did not mention the NBS approach as a panacea for urban sustainable development, since as mentioned above, it has a variety of limitations (e.g. financial mentioned above), trade-offs (such as eco-gentrification [37], ecosystem disservices [44]), and barriers [7-9,21,36]. We did not deny the importance of other concepts such as ecosystem services (ES) and urban green infrastructure (UGI), and share the ideas of Badiu et al. ([45], p. 3) that UGI plays an essential role in the NBS concept by tackling environmental problems and societal challenges in urban settings. Moreover, as highlighted by Artmann et al. [46], concepts from smart growth and green infrastructure are found to be compatible and, in our opinion, they fit with the main approaches of NBS such as functionality, smart governance and planning, compact cities, and sustainable networking. In this regard, the concept of NBSs can provide a better science-policy integration of UGI and ES approaches for addressing societal challenges, as was shown by the selected NBS intervention from Leipzig. Here, we agreed with the authors $[45,46]$ that both UGI and NBS (which involves UGI as an essential part of its concept) demonstrate their powerful tools to make cities more livable, resilient, sustainable, and better adapted to current societal challenges.

There are a number of other concepts such as the concept of a "nurtured landscape" presented by Yang and Lay [47] and proposed for mediating between the natural ecosystem and the urban/industrial environment, which corresponds with the concepts of NBS, UGI, and ES. In this regard, we can perceive the several selected NBS cases in Leipzig (e.g., Leipzig New Lakes Region, Karl-Heine Channel) to be framed into the concept of the nurtured landscape, which provides a basis for the development of new ecological technology using landscape to ameliorate the polluting effects of the urban/industrial neighbourhood for the possible remediation and revitalization of former industrial areas [47].

By examining the role of selected NBSs in the urban landscape, we can conclude that human intervention and governance can make nature an increasingly essential part in the development of cities toward the use of more resilient systems. This can be one while using the benefits that ecosystems provide and co-designing them with manufactured and technological solutions $[48,49]$ that are also needed in order to create cities that are fit for a sustainable future.

Author Contributions: Conceptualization, D.D. and D.H.; methodology, D.D. and D.H.; validation, D.H. and D.D.; formal analysis D.H. and D.D.; investigation, D.D.; resources D.D.; data curation and interpretation of results, D.D.; writing-original draft preparation, D.D. and D.H.; writing-review and editing, D.D. and D.H.; visualization, D.D.; supervision, D.H.; project administration, D.H.; funding acquisition, D.H. and D.D. All authors have read and agree to the published version of the manuscript. 
Funding: This research was funded by the Horizon 2020 Framework Programme of the European Union, research and innovation project "CONNECTING Nature-COproductioN with NaturE for City Transitioning, Innovation and Governance", Grant Agreement No 730222.

Acknowledgments: We are thankful to the CONNECTING Nature project team for their fruitful discussions regarding the NBS issues and the opportunity to learn about NBSs from a more theoretical side as researchers. We are also thankful for the opportunity to discover all the milestones, from the creation of an NBS idea to its implementation, impact assessment, and monitoring, together with different actors of NBS. Our special thanks go to the stakeholders, namely the decision makers and the active civil society of the city of Leipzig, especially from the organizations listed in the paper and their representatives who took a part in our interviews and supported us with their valuable expertise and advices. The authors also extend great gratitude to the anonymous reviewers and editors for their helpful reviews and critical comments.

Conflicts of Interest: The authors declare no conflict of interest.

\section{Appendix A. List of Interviews}

Interview 1 workshop "Essbare Stadt" (Edible City), expert from NGO (February 2018)

Interview 2 officer of Ernährungsrat (Nutrition Council) Leipzig (February 2018)

Interview 3 head officer of Rosenberg Delikatessen private company (February 2018)

Interview 4 head officer of ANNALINDE GmbH (March 2018)

Interview 5 EU NBS project expert (April 2018)

Interview 6 Kletterfix project expert (June 2018)

Interview 7 restaurant owner in response to Kletterfix project (June 2018)

Interview 8 Kletterfix project participant (house resident) who implemented a green façade in his house in the Connewitz district of Leipzig (June 2018)

Interview 9 expert from the NABU (Naturschutzbund-Nature and Biodiversity Conservation Union) NGO by Ecofestival “Ökofete” Leipzig (June 2018)

Interview 10 expert from Solar-energy Producer by Ecofestival “Ökofete” Leipzig (June 2018)

Interview 11 expert from Grüne Liga Leipzig by Ecofestival “Ökofete” Leipzig (June 2018)

Interview 12 visitor of Ecofestival "Ökofete" Leipzig (June 2018)

Interview 13 expert of Naturkundemuseum Leipzig during excursion to Leipzig Auwald (June 2018)

Interview 14 staff of Center for Environmental Information of City Leipzig-Umweltinformationszentrum Leipzig (April 2019)

Interview 15 inhabitant of prefabricated LWB housing estate in the center of Leipzig (April 2019)

Interview 16 user of allotment garden cooperative in Leipzig East (April 2019)

Interview 17 expert from NuKLA e.V./Naturschutz und Kunst-Leipziger Auwald (May 2019)

Interview 18 municipal officer of the Environment Protection department of the City of Leipzig (May 2019)

Interview 19 municipal officer of Green Space and Waters department of the City of Leipzig (May 2019)

Interview 20 staff of Kindergarden Leipzig East (June 2019)

Interview 21 visitor 1 of Lene-Voigt Park (July 2019)

Interview 22 user of ANNALINDE Gemeinschaftsgarten (August 2019)

Interview 23 staff of Neseenland Bergbautechnikpark (August 2019)

Interview 24 visitor of Neseenland area (August 2019)

\section{Appendix B. NBS Projects in Detail}

\section{Appendix B.1. Greening Façades (within the Project Kletterfix)}

Challenge: Raising awareness of the benefits of urban green spaces, financing incentives from the municipality for action of tenants and landlords on private property.

Scale of impact (Macro—region, Meso—city and district, Micro-level—street, building): micro. 
Relationship with Sustainable Development Goals_SDG [35]: SDG 3 (good health and well-being), SDG 11 (sustainable cities and communities), SDG 13 (climate action).

Temporal scale of impact (short versus long-term): long-term.

Method of implementation: Financial incentives, green infrastructure development, social networking. ES provided: Climate mitigation through improvement of urban microclimate, air purification (combat particulate matter pollution), increasing quality of life and general living conditions, aesthetic value, increase urban biodiversity (green walls as ecological corridors for flora and fauna), economic savings for tenants.

Design and main drivers: In 2015, the city of Leipzig, with the support of the Ökolöwe ecological organization, initiated a project called "Kletterfix". The goal of this initiative is to encourage citizens to become more active in terms of "urban planting" by greening their walls and façades. The implementation of green walls and façades in a growing city is a good opportunity to extend green surface by using space that is available at almost every street corner, thereby contributing to a more livable city. The Ökolöwe ecological organization provides free courses and services about greening walls and façades, and five types of climbing plants are provided free of charge as well. The project "Kletterfix-Green Walls for Leipzig" is a part of the public greening that is implemented by Ökolöwe together with the property owner. Due to the "Kletterfix" initiative, the concept of a wall-filling and easy-care greening was developed. Green walls contribute to a healthy environment in the city, and their implementation improves living conditions and microclimates. As experts of Kletterfix stated: "Not only urban parks act as a 'green lung' and cooling spot. Evaporation of the plants on the 850 square meter green façade corresponds to a cooling capacity of about 45 air conditioners. The winter heat loss of the building can also be reduced by 50\%. Green façades filter out air pollutants and fine dust, especially when implemented along roads with high traffic. Moreover, along with the air pollution control, green façades contribute to noise reduction and play the important role of being green corridors (especially for insects and small animals), which connect different green spaces within the urban green infrastructure" (Interview \#6). The campaign has already shown positive functions of façade greening, which turned out to be more and more popular amongst the population of Leipzig. For example, the owner of the Italian restaurant from the district Connewitz (Leipzig) mentioned that green façades are not only good for a greener city but are also a luxury that is unique and beautiful to look at; he says: "[The] implementation of green façades has an impressive result. It is much cooler and therefore more pleasant in the restaurant. Guests feel comfortable in the green ambience" (Interview \#7). They decided to plant wine because it expresses the Italian lifestyle and grows rapidly. "The advantage is that the desired effect of the shading has set in in a very short time", claims the restaurant manager (Interview \#7). "We also harvest the grapes in the summer and make schnapps from it. The dense green is also popular among birds" (Interview \#7). Thus, greening walls and façades can not only be good for the climate in the city but also profitable for property owners: "Such green walls not only look attractive, but also have many other advantages, including protecting the surface of buildings from direct sunlight and, as a result, reducing the cost of air conditioning, reducing noise, and increasing the oxygen content in the air. Moreover, vertical landscaping allows increases in the service life of buildings" (Interview \#8). Both sides, the city and the people, generally have a positive perception of the greening of walls and buildings, since they believe they only profit from the green façades.

\section{Appendix B.2. ANNALINDE Intercultural Garden and Urban Agriculture}

Challenge: Public space regeneration, the redevelopment of abandoned land, the renewal and redesign of public living areas to increase social cohesion and integration, raising awareness through active citizen engagement, food provision.

Scale of impact (Macro—region, Meso—city and district, Micro-level—street, building): meso.

Relationship with Sustainable Development Goals_SDG [35]: SDG 3 (good health and well-being), SDG 10 (reduced inequalities), SDG 11 (sustainable cities and communities), SDG 12 (responsible consumption and production), SDG 13 (climate action), SDG 14 (life on land).

Temporal scale of impact (short versus long-term): long-term. 
Method of implementation: Sharing knowledge, social networking, change in physical infrastructure, green infrastructure.

ES provided: Climate-change mitigation and adaptation through a range of provisioning, regulating, and cultural ecosystem services: providing food, water regulation through unsealed soils, improved air circulation and cooling through plant transpiration and shading, mitigation and adaptation to the urban heat island effect, habitat for wildlife and genetic diversity, cultural ecosystem services (leisure and recreation, promoting health and well-being, as well as a sense of place, cultural identity, and social cohesion).

Design and main drivers: Similar to the other German cities (e.g., Cologne, Berlin, Göttingen, Munich, etc.) Leipzig has developed an innovative approach to urban food growing. Amongst the best examples are its intercultural gardens, which refer today to the integral part of the German community gardens (they number more than 100 located across Germany). Their main goal is intercultural exchange, which attracts people from diverse backgrounds (e.g., social, national, cultural, etc.) and helps them better integrate into the ever more multicultural society by discovering and sharing different aspects of food culture. As a proportion of inhabitants, Leipzig is the city with the greatest number of allotments in Germany, which is due to the active allotment movement that had already been established in the 1860s. In the 20th century, a great number of bottom-up initiatives have greatly contributed to the appearance of nationally and socially oriented urban agricultural projects, mostly focusing on regional food growing. Significantly, the first intercultural garden was established in Göttingen in 1995 (Internationale Gärten), and the second one was founded in Leipzig in 2001 (Bunte Gärten) in the former footprint of an unused municipal horticultural nursery [50]. "Beginning in 2011, the ANNALINDE community garden has initiated a number of projects related not only to the food growing site but to the broad spectrum of issues related to the future development of Leipzig (such as the participatory use of urban space, environmental education programs)" (Interview \#4).

Established in 2011, ANNALINDE originated in the cooperative initiative and creativity of young people having fun on green business activities in the western districts of Leipzig. "Our goal is to create places of exchange and learning on issues of local and ecological food growing, biodiversity, sustainable consumption, responsibility in resource use, and a sustainable neighborhood and urban development. Thus, ANNALINDE provides an ideal combination of all aspects such as urban ecology, land management, urban gardening, and so on." (Interview \#4). Since 2018, ANNALINDE has operated in the eastern districts of Leipzig as well; in particular, Gärtnerei Ost (an urban gardening and nursery project in Eastern Leipzig) was created near the S-Bahnhof Station Anger-Crottendorf. Briefly explained, ANNALINDE includes a community garden and was the first area. The second one was the Gärtnerei West (urban gardening and nursery project in Western Leipzig), which was established in 1870 and is now a cultural monument of the Municipality of Leipzig.

The urban gardening of ANNALINDE can be assessed as a multifunctional urban nature-based solution. Besides providing food, it contributes to water regulation through unsealed soils, improved air circulation and cooling through plant transpiration and shading, and offers microclimate oases to many users, visitors, and neighbors. It also can help mitigate the urban heat island effect. Another important ecosystem service provided by urban gardening is a habitat for wildlife and genetic diversity. Cultural ecosystem services include opportunities for leisure and recreation, promoting health and well-being, as well as a sense of place, cultural identity, and social cohesion, all of which are important factors for societies that are adapting to change.

\section{Appendix B.3. ANNALINDE Academy}

Challenge: To develop joint and experience-based learning toward urban resilience and sustainable development, shaping environmental culture, contributing to sustainable urban living.

Scale of impact (Macro—region, Meso—city and district, Micro-level—street, building): Meso. 
Relationship with Sustainable Development Goals-SDG [35]: SDG 3 (good health and well-being), SDG 4 (quality education), SDG 11 (sustainable cities and communities), SDG 12 (responsible consumption and production), SDG 13 (climate action), SDG 14 (life on land).

Temporal scale of impact (short versus long-term): long-term.

Method of implementation: Sharing knowledge and knowledge transfer, social networking, stakeholders' and citizens' involvement, workshops.

ES provided: Cultural (information on environmental issues).

Design and main drivers: The ANNALINDE Academy was established in 2014. It was created from the community garden, firstly as a discussion platform and educational program for different aspects of sustainable urban design under the leitmotif "cultivating tomorrow". Their topics range from environmental psychology, the cyclical use of resources, and renewable energies to alternative economies. The academy is supported by the Leipzig garden program and the gallery of Contemporary Art. "Since 2015, the ANNALINDE Academy has been the interface between our three project areas-community garden, gardening, orchard-our environmental education and environmental policy work, as well as our commitment to urban and neighborhood development" (Interview \#4).

Other fields of educational activity include locally adaptable organic agriculture, urban gardening, biodiversity, sustainable urban development, food sovereignty, environmental justice, the campaign for an Edible City in Leipzig, lectures and workshops for multipliers and interested parties, and the regular environmental education programs in schools and daycare centers.

"The ANNALINDE Academy perceives itself as a place of experience-based and action-oriented learning through a co-constructive learning approach, including co-creation and co-development and acting live on-site. [...] we can experience our topics through touch, taste, and participation and convey creative competence" (Interview \#4). This is an approach in which theoretical knowledge is linked with practical activities and concrete implementation possibilities, making the academy an open platform for knowledge exchange.

\section{Appendix B.4. Project "Edible City" (Essbare Stadt)}

Challenge: To support sustainable regional agriculture and local food production, gardening movement aiming to turn the city into an edible garden.

Scale of impact (Macro—region, Meso—city and district, Micro-level—street, building): Macro.

Relationship with Sustainable Development Goals-SDG [35]: SDG 2 (zero hunger), SDG 3 (good health and well-being), SDG 10 (reduced inequalities), SDG 11 (sustainable cities and communities), SDG 12 (responsible consumption and production), SDG 13 (climate action), SDG 14 (life on land).

Temporal scale of impact (short versus long-term): long-term.

Method of implementation: Sharing knowledge, social networking, workshops.

ES provided: Regulating and cultural ecosystem services.

Design and main drivers: "Edible City" ("Essbare Stadt") appeared in 2014 as an initiative of young and cooperative people [51]. The concept came out of a series of workshops on social agriculture. The organization responsible for its development is ANALINDE (NGO). "The initiative 'Edible City' is about food cultivation in public spaces. On the one hand, it is about those spaces where people can garden and harvest. On the other hand, many fruits and herbs are already growing in public spaces; thus, this project includes the mapping of and informing about harvesting possibilities. It also aims to make Leipzig an edible city and create and implement certification for [producing] and marketing the food" (Interview \#1). Community gardens and market gardens are being used for cooperative learning about local ecological food production, biological diversity, sustainable consumption, and the economy, which can empower the idea of a sustainable society. The city council has allocated 150,000 Euros for the promotion of community garden projects for the years 2019 and 2020.

The "Edible City" concept includes two main strategies: revitalizing urban communally owned brownfield sites and replacing decorative planting in public parks and other non-food-growing green facilities (such as pocket parks, backyards, etc.) with edibles. "It not only contributes to increasing the 
biodiversity and improving the quality of green spaces, but also helps to engage the public (broad community), which can greatly contribute to the lowing of maintenance costs for communally owned open spaces" (Interview \#1).

One such workshop, named "Essen für alle" ("Good food for all"), was organized in February 2018. The questions discussed during the workshop ranged from "how we can feed ourselves in the city more sustainably and independently than today" to "what trends we can observe now in terms of newer developments in the food scene?" The presenters highlighted the value of the community and neighborhood gardens, as well as the classical allotment gardens, community-supported agriculture, the città slow (the slow food movement is an international network of small towns that originated in Italy less than a decade ago that is aimed at promoting slowness against the fast life and includes improving the quality of life in towns by having a cleaner environment, eating wholesome food, participating in a rich social life, and taking time out to think about what we should be doing and how we should be doing it) etc. by underlying the role of local politics and other actors in urban governance.

\section{Appendix B.5. "Nutrition Council Leipzig" (Ernährungsrat Leipzig)}

Challenge: To improve the food system in Leipzig and make it more ecological and more democratic; to ensure the long-term sustainable supply of the city's population with regional, seasonal, and healthy food.

Scale of impact (Macro—region, Meso—city and district, Micro-level—street, building): Macro.

Relationship with Sustainable Development Goals-SDG [35]: SDG 2 (zero hunger), SDG 3 (good health and well-being), SDG 10 (reduced inequalities), SDG 11 (sustainable cities and communities), SDG 12 (responsible consumption and production), SDG 13 (climate action), SDG 14 (life on land).

Temporal scale of impact (short versus long-term): Long-term.

Method of implementation: Social networking, sharing knowledge, workshops.

ES provided: Provisioning, supporting, cultural ecosystem services.

Design and main drivers: The "Nutrition Council Leipzig" was set up in 2019 in order to improve the food system in Leipzig and make it more ecological and more democratic. The first nutrition councils in Germany were founded in 2016 in Berlin and Cologne. The "Nutrition Council Leipzig" is an association of civil society groups, farmers, processors, retailers, and restaurateurs from Leipzig and the region, as well as representatives of the municipality. "It was set up for better dialogue between different stakeholders for a better meal" (Interview \#3). One of the biggest global challenges in the 21st century is the production and availability of healthy food. Against the background of climate change and the constant decline of biodiversity, it is also necessary to develop a sustainable agricultural system at the regional level. Therefore, "Leipzig wants to emphasis a local political agenda and ensure the long-term sustainable supply of regional, seasonal, and healthy food to the city's population" (Interview \#2). In doing so, the Nutrition Council Leipzig is involved in three main activities: (1) it connects different actors within the food system in the city; (2) it collects knowledge about the production, marketing, and supply of the food in the region; and (3) it performs an advisory function and appears as a platform for education and informational exchange.

"We have to highlight one important role of such nutrition councils, namely that they are a tool for food policy 'from the bottom'" (Interview \#2). The main idea for the foundation of the Nutrition Council, its goals and visions, as well as important milestones for its successful implementation, are the following: "More and more people today are committed to sustainable change in agriculture, food production, and consumption style: you participate in community gardens or solidarity, agriculture, cooking for others, sharing your food, organizing discussion events, or going for a different agricultural policy on the road. These diverse civil society initiatives and actors come together in nutrition councils and jointly develop policies for the renewal of our nutrition systems" (Interview \#2). One of the indicators of success is the city's support: "In this regard, the City of Leipzig makes its great contribution in giving financing support for such kind of initiatives and networks" (Interview \#1).

Another set of activities promoted by the Nutrition Council include those that refer to the sharing and learning initiatives for a different food culture: "Our eating habits are very diverse and, at the same 
time, characterized by social norms, habits, and incentive structures. This initiative is aimed to education at sustainable nutrition in the sense of fair food culture" (Interview \#2).

"I am interested in the work of this organization (Nutrition Committee Leipzig) and will attend the next meetings for sure. I think different aspects will be discussed that relate to my business. Especially how projects like mine could be supported. And I would like to understand the processes from inside in order to understand in depth what the driving forces for transformations in society are, for shift of life-models and method of product consumption" (Interview \#3).

\section{Appendix B.6. Lene-Voigt Park (Renaturing of Former Industrial Area to Public Green Space)}

Challenge: To renature the post-industrial area to public green space, to connect eastern districts and the 'green lungs' of the city (park as a part of green belt), to initiate residential change of the surrounding areas and the development of the local urban infrastructure.

Scale of impact (Macro—region, Meso—city and district, Micro-level—street, building): meso.

Relationship with Sustainable Development Goals_SDG [35]: SDG 3 (good health and well-being),

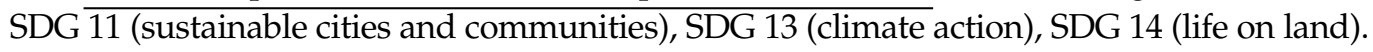

Temporal scale of impact (short versus long-term): Long-term.

Method of implementation: Change in physical infrastructure, green infrastructure development, social networking.

Indicators of success: Co-creation with residents (through workshops), offering more green space for the dense housing area, increasing in the attractiveness of place and district.

ES provided: Climate mitigation and adaptation, habitat provision, recreation

Design and main drivers: Lene-Voigt Park is a good example of the successful renaturing of the former heavily disturbed area of the Eilenburg railway station, which was formerly located on this site. Now, it is a very popular place of recreation for people of all ages that was created in 2001 and officially opened in 2004. From the time of its completion in 1874, the approximately 11 ha area Eilenburger Bahnhof (Railway Station) together with other four railway stations made Leipzig one of the important railway junctions of the former German Empire. After the construction of the Central Railway Station in 1915, passenger traffic was largely relocated there. In 1942, the operation at the Eilenburg railway station was completely discontinued, and the site was mostly neglected. An $800 \mathrm{~m}$ long and 80-130 m wide area remained behind in a prominent location close to the city center [12-14].

In an area characterized over several decades by vacant buildings and extensive brownfields, the park has become part of a green belt connecting the eastern districts and the "green lungs" of the city. Residents' opinions and desires were included in the process of its creation through workshops. The main aim of the creation of this park was to offer more green space for the dense housing area and to create playgrounds for kids. The park was well received and became popular shortly after it was completed. It helped to initiate the residential change of the surrounding areas and the development of the local urban infrastructure, e.g., cafés and shops. New residents moved there, and housing vacancies started to decrease. Among the new residents, there were more young families with children and higher incomes. As a consequence, rents started to rise from 4.5 Euro per square meter in 2000 to almost 7 Euro per square meter as of today. Lene-Voigt Park is the heart of an increasingly expensive housing area for young and educated residents. Former residents of the area, including elderly and less affluent households, had to leave due to increasing housing costs.

"The aim of the redevelopment of this area was not only to preserve and restore the historic quality and complexity of the district, but also to create a district (neighborhood) park that invites you to play and recover and that continues in a green radius towards the outskirts of the city" (Interview \#19).

An interesting detail is that park was created by the active involvement of local inhabitants in the project planning. As a result, a number of sport facilities (table tennis tables, playing fields for ball sports, as well as opportunities for boules, inline skating, and mountaineering), children's playgrounds (including a fairytale forest and sand island for tasting and creating), and places for picnics make this park popular among young people and families with children. 
A direct connection from Lene-Voigt-Park to the "Grünen Ring" (Green Belt) around Leipzig forms the walking and cycling path and is an important element of Leipzig's green infrastructure. In 2002, Lene-Voigt Park received the European prize for landscape architecture, as the concept deliberately provided a lot of space for civic engagement and participation. There are a number of citizen's forums and workshops that are organized here yearly and which contribute to the raising of awareness of all the related sustainable goals. These also provide a platform where the critical opinions of different urban actors can be stated out loud, and the creativity of local residents can be shown.

One of the important elements of design of the Lene-Voigt Park includes spaces for nature experiences (Naturerfahrungsräume). This concept offers spaces for nature experiences and was developed in the 1990s. These are near-natural sites that provide opportunities for children to play in an unregimented and largely unsupervised way.

Appendix B.7. Eco-Food Project "Rosenberg Delikatessen"

Challenge: To establish a green business/company, to use regional food/products, to support regional variations of materials and energy balance.

Scale of impact (Macro—region, Meso—city and district, Micro-level—street, building): Macro.

Relationship with Sustainable Development Goals_SDG [35]: SDG 3 (good health and well-being), SDG 11 (sustainable cities and communities), SDG 12 (responsible consumption and production), SDG 13 (climate action), SDG 14 (life on land).

Temporal scale of impact (short versus long-term): Long-term.

Method of implementation: Social networking, sharing knowledge, financial incentives.

Indicators of success: Continuous development of innovative strategies to make the products better, respect to traditional processing/manufacturing of regional fruits and vegetables, good networking that involves different actors.

ES provided: Provisioning, supporting, cultural.

Design and main drivers: Rosenberg Delicatessen was founded in 2016 as a joint private company driven by the idea of producing bio(eco)products from the fruits and vegetables growing and cultivated in the region of Leipzig, in close cooperation with bio-shops of eco-food (orchards). The private company is involved in a network of actors who are dealing with the distribution, landscaping, and landscape conservation as well as environmental protection aspects and the processing of fruits and further production.

"As for me, the term NBS is first of all related to human well-being and health [ ... ] and also to the aspects such as establishing a green business/company, using regional food/products, supporting regional variations of materials, and energy balance [... ] In this sense, my case fits well" (Interview \#3).

The project " $[$... ] first of all [ ... ] aims to strengthen regional material cycles as well as the production and processing of fruits and vegetables in the Leipzig region. One of the important goals is raising the awareness of such topics as the Edible City and healthy food in the population" (Interview \#3).

"[ ... ] A network of people dealing with the subject of the Edible City is very important for my company, with ideas on regional development, local production, landscaping, fruit, local food producers, landscape care, and nature conservation. I am glad to be involved in the network of producers of local foods and to better understand what moves the people, what they offer, and what they consume [... ] How are citizens engaged with the aspects of healthy food, green space, [and] healthy nutrition, and what do they do for that? For me, these are the important areas of experience" (Interview \#3).

"In fact, Rosenberg Delikatessen can be perceived as an NBS experiment that refers to the continuous process started in 2016 and that will further develop. Last week (February 2018), I met people and we discussed the idea of new orchards for the city and who will handle, process, and maintain them. Thus, it is the networking that involves developing and maintaining connections with different individuals, the process of establishing a mutual beneficial relationship between them" (Interview \#3).

By highlighting the factors of success, the following can be identified as the most prominent: "[ ... ] I have monthly bookkeeping and accounting. This is a good thing. Thanks to this, I notice how dynamic 
everything is [...] Also, a website was established and it helps me [...] to reflect on all activities within the project that I am working on and, especially, to develop new strategies. [ .. . ] Currently, I am developing a web shop. So, I had learned and [I] apply different strategies on how to start a private company, how to make the products and the regions well known on the market, and [how] to promote them" (Interview \#3).

Another key to the success of the experiment, as identified by the company chair, is "[ .. ] not only the love of my work ('die liebevolle Handarbeit') and the respect for traditional processing/manufacturing of regional fruits, but also good networking that involves different actors" (Interview \#3). Thus, the goal of Rosenberg Delicatessen's establishment was not primarily connected to total the profit-maximization objective, but first of all that "[ ... ] regional products made from the fruits growing and cultivated in the region of Leipzig will be presented and well-known on the market. [... ] Then, they will be processed in the regional products and finally will be sold and consumed also locally. So, it uses less energy [and] transportation resources and is healthy for people" (Interview \#3).

If the city and surroundings get more orchards, this means that it will provide more habitat for animals and plants and biodiversity support. It also means more space for leisure and recreation by citizens, the development of green infrastructure, and support for local food organizations and private companies. In addition, it provides a healthy lifestyle for citizens in the sense of the Edible City, where people are aware of bio-products and the importance of local food consumption as well as participate in the development of intercultural/community gardens. For instance, the Foundation of Leipzig's Citizens ("Stiftung Bürger für Leipzig") promotes this initiative, and it will be decided in the near future where such areas will be established.

Appendix B.8. Ecological Festivals (Umwelttage and Ökofete)

Challenge: Raising awareness of environmental issues, stakeholders' and citizens' involvement. Scale of impact (Macro-region, Meso-city and district, Micro-level—street, building): Macro. Relationship with Sustainable Development Goals-SDG [35]: SDG 3 (good health and well-being), SDG 10 (reduced inequalities), SDG 11 (sustainable cities and communities), SDG 12 (responsible consumption and production), SDG 13 (climate action), SDG 14 (life on land).

Temporal scale of impact (short versus long-term): Long-term.

Method of implementation: Sharing knowledge and knowledge transfer, social networking. ES provided: Cultural.

Design and main drivers: The annual Leipzig Environment Days ("Umwelttage") have offered a colorful program since 1990 with over 100 environmental events in and around Leipzig. They normally commence on 5 June (World Environment Day) and include a variety of events around the topics of environment, sustainability, and nature conservation. They allow citizens of all ages to explore, experience, and discover related issues with films, excursions, discussions, guided tours, lectures, concerts, and much more. As a highlight of the green event, at the end of the Environment Days, the Ecofestival is organized in Clara Zetkin Park, which has a rich program dedicated to environmental protection, sustainable, and environmentally friendly consumption, and eco-friendly products. The festival offers an opportunity for everybody to communicate with representatives of the government, various environmental organizations, political units, and producers of eco products regarding their activities and the current environmental issues that the city of Leipzig faces. "The Leipzig Environment Days show how sustainable and environmentally friendly our life in the city can be. A variety of eco-products are presented there, including apples from the local market place, noodles unpacked into the glass, T-shirts made of fair-trade organic cotton, and other sustainable products" (Interview \#9).

The program includes different activities and excursions. One of these is the excursion to the green paradise in the middle of the city, the Leipziger Auwald, where participants can find out which animals and plants are at home here (native species) and which were introduced but have now found their habitat. A large portion of the activities and events is devoted to the issue of whether gardeners in a big city such as Leipzig can be close to nature. 
"You can learn how easily and ecologically the fruits and vegetables can be grown in your own garden or backyard. This we got thanks to the Leipzig Environment Days" (Interview \#12).

"Here, you can not only buy organic products such as food and beverages, but also learn something about the current environmental issues, smart solutions, and about those in Leipzig (associations, offices, companies, individuals) who are contributing to making the environmental situation better" (Interview \#9).

Appendix B.9. City's tree Planting Program (Baumstarke Stadt)

Challenge: Achieve more green in the city, improve air quality, and reduce noise, citizen and stakeholder involvement.

Scale of impact (Macro—region, Meso-city and district, Micro-level—street, building): Meso.

Relationship with Sustainable Development Goals-SDG [35]: SDG 3 (good health and well-being), SDG 11 (sustainable cities and communities), SDG 13 (climate action), SDG 14 (life on land).

Temporal scale of impact (short versus long-term): Long-term.

Method of implementation: Green infrastructure development, change in legislation or regulation, social networking.

ES provided: Climate change mitigation and adaptation, air purification (increasing air quality and reducing noise), cultural.

Design and main drivers: The city of Leipzig initiated the project Tree-Strong City ("Baumstarke Stad "') in 1996-1997 [52]. This NBS initiative has been implemented by the city authorities in order to attract people's attention to modern ecological issues and increase the popularity of ecological movements among the population by reforesting streets in the city. The aim of this project is to increase the tree stock in the city by planting new trees in public areas such as parks, streets, urban cemeteries, etc. The initiative consists of tree sponsorship bids starting from 250 Euros paid by citizens or companies who are going to be a sponsor for the particular tree. The sponsorships include an oak stele with a sign on it that indicates tree species and a personal message. This personal dedication can commemorate any special occasion or event (birthday, anniversary, graduation, etc.). Thus, the Tree-Strong City initiative in Leipzig is a creative and beneficial way to reforest the streets, which ultimately improves the quality of life since trees provide fresh air and contribute significantly to a livable, green city. This project contributes to a greener city landscape and strengthens the attachment of citizens to their urban environment.

\section{Appendix B.10. Leipziger Neuseenland (Leipzig New Lakes Region)}

Challenge: Revitalization of the post-mining area, regeneration of a vast mining landscape.

Scale of impact (Macro—region, Meso—city and district, Micro-level—street, building): Macro.

Relationship with Sustainable Development Goals-SDG [35]: SDG 3 (good health and well-being), SDG 9 (industry, innovation, and infrastructure), SDG 11 (sustainable cities and communities), SDG 13 (climate action), SDG 14 (life on land).

Temporal scale of impact (short versus long-term): Long-term.

Method of implementation: Change in physical infrastructure, change in legislation or regulation (federal program), green infrastructure development, networking.

Indicators of success: State-driven initiative, supported by private companies, focusing on enhancing the attractiveness of the area, providing new recreation facilities, and generating economic growth and employment through tourism.

ES provided: Climate adaptation and mitigation, biodiversity and habitation provision, climate and water regulation, recreation, cultural ES.

Design and main drivers: The region has a long tradition of mining activity, which has constituted the most important sector of the regional economy. The first open pit appeared in the area in 1900. During the existence of the GDR, the coal industry was actively developed, as there was no access to the West German deposits. The consequence was a significant deterioration of the environment, so the air in Leipzig and its surroundings was considered to be the most polluted in all of Europe. Sprawling 
quarries and empty rock dumps occupied a huge territory, and tens of thousands of people were relocated to other regions. Active land reclamation started in the 1990s, since after the reunification of Germany, the demand for coal fell, and work at many quarries ceased. The question was what to do with such a large area of land from the former developments (the total area of the former quarries was $18,000 \mathrm{ha}$, the depth of some reached $100 \mathrm{~m}$ ). As part of the remediation, new reservoirs have been formed and continue to be created. A plan exists to connect these together (at the moment, 15 lakes have been created with different purposes, including recreation or environmental protection). The total water surface area of the plans is 70 square $\mathrm{km}$.

In recent decades, many traditional European centers of the mining industry have been rendered unprofitable, which has led to the closure of the pits. In addition, such regions as middle Germany, in which Leipzig is centered, started to face environmental issues in the form of persistent pollution of the water, soil, and air. Those environmental issues led to the closure of the coal industry in the region and required the revitalization of the ground, which led to the foundation of a new recreational area called Neuseenland. Nowadays, this region has become one of the most popular destinations for relaxation, sunbathing, fishing, and yachting. There is an industrial museum founded here to show the history of the coal mining in the region and its transformation after the reunification of Germany.

"In the 1990s, it was decided that a museum would be established that would tell the history of the coal industry in the region of Leipzig. Different types of big industrial machines, which had been used for mining, are exhibited in our open-air museum. Mostly, people, visiting this museum are interested in the coal industry and the history of the Leipzig region, but there are not that many visitors. Our exhibits are hard to miss on the horizon. They are huge. Those machines are visible from far away, from Lake Markkleeberg where people come to swim and relax during the summer. Kanupark is also there, which is very popular among locals and tourists. Some people visit just because they want to know what is here. And, even though most of the people don't reach the museum, they still get involved in the mining history of the region because they swim or yacht in the lakes created on the site of the former coal mines. School groups visit for educational purposes during the academic year. It seems to me that our museum is very interesting and unusual" (Interview \#24).

At the moment, recreational nature management is developing in the former industrial territory. The functional use of the territory has transformed from an industrial one to a recreational one. One such famous touristic object is Canoe Park, which was created on Lake Markkleeberger and Lake Cospudener. The tourist infrastructure of the park is well developed, and there are visual maps of the functional zoning of the park at the entrance so that all guests can easily find what they need. On the banks of beaches, there are cafés, restaurants, developing infrastructure for water sports, and an amusement park located near the technical Park Museum that is dedicated to the mining industry. At the entrance, there is a map of the geological structure of the territory of the former quarries. The park for water sports activities was built as part of the promotion of Leipzig as a candidate for the 2012 Summer Olympics. In this area, there is a hotel consisting of cottages and apartments, which is equipped with a developed tourist infrastructure for a comfortable year-round stay. The development of infrastructure continues. Many people, including children, visit for water sports and just relax on the shores of the lakes. In addition to recreational activities, the former industrial area is used for power generation, and a large area is occupied by solar panels located on the slopes of the waste-rock dumps.

In general, it should be noted that this method of reclamation of the former industrial territory was chosen and executed very successfully. The transportation infrastructure within the park is constantly developing and is maintained at a high level (both personal and public transport). This makes the park even more popular among tourists and vacationers of all ages. "Everyone can find something that he/she likes, from professional athletes who have the opportunity to train (water sports) to a quiet family holiday with children in a comfortable hotel on the lake" (Interview \#25). 


\section{Appendix B.11. Karl-Heine Channel}

Challenge: To deal with the consequences of industrialization and deindustrialization, to renature and recover the river courses and wetlands, ponds and lakes, sustainable redevelopment of the post-industrial landscape.

Scale of impact (Macro—region, Meso—city and district, Micro-level—street, building): Meso.

Relationship with Sustainable Development Goals_SDG [35]: SDG 3 (good health and well-being), SDG 6 (clean water and sanitation), SDG 11 (sustainable cities and communities), SDG 13 (climate action).

Temporal scale of impact (short versus long-term): Long-term.

Method of implementation: Change in physical infrastructure, change in legislation or regulation, green infrastructure development, monitoring.

Indicators of success: Support from federal policy and programs, ecological revitalization as one of the main goals of policy after German reunification in order to harmonize living conditions in the east and the west (e.g., ecological transition as a part of welfare policy), federal money stemming from subsidies to the labor market, active participation of civil society.

ES provided: Improvement of the environmental situation, redevelopment of an area that makes the residential area attractive for new restaurants and businesses.

Design and main drivers: The Karl-Heine Channel is a 3.3-km long artificial water route west of Leipzig (it terminates near Lindenau port). The channel was created in 1856-1898 on the Initiative of the Leipzig lawyer and industrial pioneer Carl Heine as the first part of a projected shipping channel from the White Elster up to the Saale. In the 1990s, the canal was revitalized. In 1996, a cycle path was set up on the northern canal bank. In 2007, the municipality decided to extend the canal to the port in order to enable the long-planned connection to Leipzig [26]. By 2015, 18 million Euro had been invested in the project, including funding from the municipality, land sales, and the EU Urban Development Fund. Another source indicates that the total costs of the construction project will come to 9.997 million Euro, including planting and landscaping works. Thus, having originally followed the natural course of the river, the canal was redesigned with a strong emphasis on urban development. The revitalization of the channel also contributed to the attractiveness of the whole western district of Leipzig, transforming it from the one of the most polluted and deteriorated into the so-called "Leipzig's Venice". "This manmade canal doesn't have to be explored by boat. A cycle lane leads from the Nonnenbrücke (bridge) to the Luisenbrïcke (bridge) through several interesting sightseeing spots such as the 'Riverboat', the MDR's former talk-show studio. In between, you will spot grand villas, ultramodern industrial lofts, and lovely places to stop and enjoy" (Interview \#23).

\section{Appendix B.12. Leipziger Auwald (Riverside/Riparian Forest)}

Challenge: Development and conservation of the local floodplains, to restore natural habitats and provide ecological benefits as well as opportunities for environmental learning and citizen participation.

Scale of impact (Macro—region, Meso—city and district, Micro-level—street, building): Macro.

Relationship with Sustainable Development Goals_SDG [35]: SDG 3 (good health and well-being), SDG 11 (sustainable cities and communities), SDG 13 (climate action), SDG 14 (life on land).

Temporal scale of impact (short versus long-term): Long-term.

Method of implementation: Change in legislation or regulation, green infrastructure development, monitoring, social networking, sharing knowledge.

Indicators of success: Raising awareness of the importance of the floodplain and its related ecosystem services to both people and nature.

ES provided: Mitigation of flood risk, cleaning water by nutrient retention, delivering oxygen, fixating carbon dioxide in the production of floodplain forests, enrichment of quality of life for citizens by providing people with an enjoyable place of rest, relaxation, and recreation.

Design and main drivers: In Leipzig, the development of the city and the forest are closely interrelated, not least because one of the largest floodplain forests areas of Central Europe is situated in the urban territory of Leipzig. Indeed, the urban floodplain forest is the backbone of the city's 
multifaceted green network that includes lots of parks, gardens, and allotments and that contributes to the high quality of life in our city. This green network is complemented by a system of rivers and water courses that cross the city and shape the cityscape [53]. Awareness of the city's blue infrastructure is now emerging due to the reconstruction and rehabilitation of canalized water courses, the improvement of water quality, and the river system. In recent years, it has developed into a significant attraction for Leipzig's citizen as well as for the tourism business in the region [54].

In order to revitalize the floodplains of Leipzig and Schkeuditz in 2012, and especially the river and riparian forest landscapes, the project Live Luppe River ("Lebendige Luppe") was launched. A variety of negative changes and consequences for the wetlands appeared due to intensive human activities in the past such as flood and stream controls, embankment sealing, and the drainage of arable land and meadows. One of these activities was the regulation of the "New Luppe" river, which embanked in the 1930s, causing ecological damage due to droughts and missing groundwater contact in the floodplains $[16,17]$. It resulted in the situation that a riverine landscape that had once regularly flooded now suffered from a marked reduction in groundwater and inundation. This developed alongside the progressive drying of habitats and poses a threat to the floodplain biodiversity and related ecosystem services.

The afforestation of urban forests on derelict land introduces a new type of urban green space and offers an ecologically, economically, and socially viable alternative to costly designed green spaces [53]. In the long term, the urban forests shall be managed similar to rural forests and, at the same time, serve as neighborhood parks. Through a thorough process, suitable sites for urban forests in the inner-city area were selected. By now, two of them have been afforested. The implementation of the project is accompanied by comprehensive research design, which will clarify the effects of urban forests on the urban climate, biodiversity, recreation, population, and urban redevelopment.

\section{References}

1. Albert, C.; Schröter, B.; Haase, D.; Brillinger, M.; Henze, J.; Herrmann, S.; Gottwald, S.; Guerrero, P.; Nicolas, C.; Matzdorf, B. Addressing societal challenges through nature-based solutions: How can landscape planning and governance research contribute? Landsc. Urban Plan. 2019, 182, 12-21. [CrossRef]

2. Scott, M.; Lennon, M.; Haase, D.; Kazmierczak, A.; Clabby, G.; Beatley, T. Nature-based solutions for the contemporary city. Plan. Theory Pract. 2016, 17, 267-300. [CrossRef]

3. European Commission. Towards an EU Research and Innovation Agenda for Nature-Based Solutions and Re-Naturing Cities; CEC: Brussels, Belgium, 2015.

4. European Commission. Policy Topics: Nature-Based Solutions. 2016. Available online: https://ec.europa.eu/ research/environment/index.cfm?pg=nbs (accessed on 15 August 2019).

5. Urban Agenda for the EU. Sustainable Use of Land and Nature-Based Solutions Partnership. Draft Action Plan. 2018. Available online: https://ec.europa.eu/futurium/en/sustainable-land-use/introduction-draftaction-plan-sustainable-use-land-and-nature-based-solutions (accessed on 23 July 2019).

6. Raymond, C.M.; Berry, P.; Frantzeskaki, N.; Kabisch, N.; Breil, M.; Nita, M.R.; Geneletti, D.; Calfapietra, C. A framework for assessing and implementing the co-benefits of NBS in urban areas. Environ. Sci. Policy 2017, 77, 15-24. [CrossRef]

7. Kabisch, N.; Frantzeskaki, N.; Pauleit, S.; Naumann, S.; Davis, M.; Artmann, M.; Haase, D.; Knapp, S.; Korn, H.; Stadler, J.; et al. Nature-based solutions to climate change mitigation and adaptation in urban areas: Perspectives on indicators, knowledge gaps, barriers, and opportunities for action. Ecol. Soc. 2016, 21, 39. [CrossRef]

8. Kabisch, N.; Korn, H.; Stadler, J.; Bonn, A. Nature-Based Solutions to Climate Change Adaptation in Urban Areas: Linkages between Science, Policy and Practice; Springer International Publishing: New York, NY, USA, 2017. [CrossRef]

9. Nesshoever, C.; Assmuth, T.; Irvine, K.J.; Rusch, G.M.; Waylen, K.A.; Delbaere, B.; Haase, D.; Jones-Walters, L.; Keune, H.; Kovacs, E.; et al. The science, policy and practice of Nature-Based Solutions: An interdisciplinary perspective. Sci. Total Environ. 2017, 579, 1215-1227. [CrossRef] [PubMed] 
10. Almassy, D.; Pinter, L.; Rocha, S.; Naumann, S.; Davis, M.; Abhold, K.; Bulkeley, H. Urban Nature Atlas: A Database of Nature-Based Solutions Across 100 European Cities. Report of H2020 Project Naturvation. 2018. Available online: https://naturvation.eu/sites/default/files/result/files/urban_nature_atlas_a_database_ of_nature-based_solutions_across_100_european_cities.pdf (accessed on 15 June 2019).

11. Haase, D.; Dushkova, D. Learning from existing nature-based solutions experiences in Europe. In Connecting Nature: Bringing Cities to Life, Bringing Life into Cities; Deliverable 1.1.2018 of H2020 Project Connecting Nature; Unpublished document; 2018.

12. Rink, D. Stadt der Extreme. Leipz. Bl. Sonderh. 2015, 1000, 4-7.

13. Haase, D.; Dushkova, D.; Haase, A.; Kronenberg, J. Green infrastructure in postsocialist cities: Evidence and experiences from Russia, Poland and Eastern Germany. In Post-Socialist Urban Infrastructures; Tuvikene, T., Sgibnev, W., Neugebauer, C.S., Eds.; Routledge: London, UK, 2019; pp. 105-122.

14. Rink, D.; Behne, S. Grüne Zwischennutzungen in der wachsenden Stadt: Die Gestaltungsvereinbarung in Leipzig. Stat. Quart. 2017, 1, 39-44.

15. Wolff, M.; Haase, A.; Haase, D.; Kabisch, N. The impact of urban regrowth on the built environment. Urban Stud. 2016, 54, 2683-2700. [CrossRef]

16. Haase, D. Urban ecosystem, their services and town planning. Critical reflections of selected shortcomings. Urbanistica 2017, 159, 90-94.

17. Haase, D. Urban wetlands and riparian forests as a nature-based solution for climate change mitigation and adaptation in cities and their surroundings. In Nature-Based Solutions to Climate Change in Urban Areas: Linkages of Science, Society and Policy; Kabisch, N., Bonn, A., Korn, H., Stadler, J., Eds.; Springer International Publishing: New York, NY, USA, 2017; pp. 111-122. [CrossRef]

18. Connop, S.; Vandergert, P.; Eisenberg, B.; Collier, M.J.; Nash, C.; Clough, J.; Newport, D. Renaturing cities using a regionally focused biodiversity-led multifunctional benefits approach to urban green infrastructure. Environ. Sci. Policy 2016, 62, 99-111. [CrossRef]

19. Connop, C.; Dushkova, D.; Haase, D.; Nash, C. Contributions to the European Handbook on Impact Assessment: Indicators Factsheets; Connecting Nature Project (Internal Report); Unpublished document; 2019.

20. Nature4Cities. NBS Multi-Scalar and Multi-Thematic Typology and Associated Database; Project Deliverable D1.1. 2018. Available online: https://docs.wixstatic.com/ugd/55d29d_8813db2df690497e80740537b6a8a844. pdf (accessed on 15 June 2019).

21. Sekulova, F.; Anguelovski, I. The Governance and Politics of Nature-Based Solutions; Naturvation, Deliverable 1.3: Part VII; Ashgate Publishing: Farnham, UK, 2017.

22. Haase, D.; Dushkova, D. Naturbasierte Lösungen für Umweltprobleme in Städten-Ein Anwendungsfall für Die Stringente Umsetzung von Urbanen Ökosystemleistungen? Innovationsnetzwerk Ökosystemleistungen Deutschland (ESP-DE). 2019. Available online: https://www.esp-de.de/naturbasierte-loesungenfuer-umweltprobleme-in-staedten-ein-anwendungsfall-fuer-die-stringente-umsetzung-von-urbanenoekosystemleistungen/ (accessed on 2 August 2019).

23. Cohen-Shacham, E.; Walters, G.; Janzen, C.; Maginnis, S. Nature-Based SOLUTIONS to Address Global Societal Challenges; IUCN: Gland, Switzerland, 2016.

24. Cohen-Shacham, E.; Andrade, A.; Dalton, J.; Dudley, N.; Jones, M.; Kumar, C.; Maginnis, S.; Maynard, S.; Nelson, C.R.; Renaud, F.G.; et al. Core principles for successfully implementing and upscaling Nature-based Solutions. Environ. Sci. Policy 2019, 98, 20-29. [CrossRef]

25. Gutiérrez, L.; García, G.; García, I. Nature-Based Solutions for Local Climate Adaptation in the Basque Country: Methodological Guide for Their Identification and Mapping; Donostia/San Sebastián Case Study; Environmental Management Agency, Ministry of the Environment, Territorial Planning and Housing-Basque Government; Ihobe: Bilbao, Spain, 2017.

26. Stadt Leipzig. Machbarkeitsstudie zur Anbindung des Lindenauer Hafens an Dem Saale-Elster Kanal. Einleitung Stadt-Umland-Konferenz des Grünen Ringes Leipzig. 7 November 2018. Available online: https: //gruenerring-leipzig.de/wp-content/uploads/2018/11/zabojnik-liha-1.pdf (accessed on 5 September 2019).

27. Cabral, I.; Keim, J.; Engelmann, R.; Kraemer, R.; Siebert, J.; Bonn, A. Ecosystem services of allotment and community gardens: A Leipzig, Germany case study. Urban For. Urban Green. 2017, 23, 44-53. [CrossRef] 
28. Bundesministerium für Umwelt, Naturschutz, Bau und Reaktorsicherheit (BMUB). Die Leipzig Charta zur Nachhaltigen Europäischen Stadt [The Leipzig Charter on Sustainable European Cities]; BMUB: Berlin/Heidelberg, Germany, 2007. Available online: https://www.bmi.bund.de/EN/topics/building-housing/city-housing/nationalurban-development/leipzig-charter/leipzig-charter-artikel.html (accessed on 10 August 2019). (In German)

29. Perkins, H.A. Green spaces of self-interest within shared urban governance. Geogr. Compass 2010, 4, $255-268$. [CrossRef]

30. Maes, J.; Jacobs, S. Nature-Based Solutions for Europe's Sustainable Development. Conserv. Lett. 2015, 10, 121-124. [CrossRef]

31. Elmqvist, T.; Andersson, E.; Frantzeskaki, N.; McPhearson, T.; Olsson, P.; Gaffney, O.; Takeuchi, K.; Folke, C. Sustainability and resilience for transformation in the urban century. Nat. Sustain. 2019, 2, 267-273. [CrossRef]

32. Frantzeskaki, N.; Hölscher, K.; Bach, M.; Avelino, F. Co-Creating Sustainable Urban Futures: A Primer on Applying Transition Management in Cities; Springer International Publishing: New York, NY, USA, 2018. [CrossRef]

33. Pauleit, S.; Zölch, T.; Hansen, R.; Randrup, T.B.; van den Bosch, C.K. Nature-based Solutions and Climate Change-Four Shades of Green. In Nature-Based Solutions to Climate Change in Urban Areas: Linkages of Science, Society and Policy; Kabisch, N., Bonn, A., Korn, H., Stadler, J., Eds.; Springer International Publishing: New York, NY, USA, 2017; pp. 29-49. [CrossRef]

34. Biggs, R.; Kizito, F.; Adjonou, K.; Ahmed, M.T.; Blanchard, R.; Coetzer, K.; Handa, C.O.; Dickens, C.; Hamann, M.; O'Farrell, P.; et al. Current and future interactions between nature and society. In The IPBES Regional Assessment Report on Biodiversity and Ecosystem Services for Africa; Secretariat of the Intergovernmental Science-Policy Platform on Biodiversity and Ecosystem Services: Bonn, Germany, 2018; pp. 297-352.

35. United Nations. Transforming Our World: The 2030 Agenda for Sustainable Development; Division for Sustainable Development Goals, Department of Economic and Social Affairs, United Nations: New York, NY, USA, 2015. Available online: https://sustainabledevelopment.un.org/content/documents/21252030\%20Agenda\%20for\% 20Sustainable\%20Development\%20web.pdf (accessed on 23 July 2019).

36. Wright, H. Understanding green infrastructure: The development of a contested concept in England. Local Environ. 2011, 16, 1003-1019. [CrossRef]

37. Kabisch, N.; Haase, D. Green justice or just green? Provision of urban green spaces in Berlin, Germany. Landsc. Urban Plan. 2014, 122, 129-139. [CrossRef]

38. Laszkiewicz, E.; Kronenberg, J.; Marciaczak, S. Attached to or bound to a place? The impact of green space availability on residential duration: The environmental justice perspective. Ecosyst. Serv. 2018, 30, 309-317. [CrossRef]

39. Byrne, J.; Wolch, J. Nature, Race, and Parks: Past Research and Future Directions for Geographic Research. Prog. Hum. Geogr. 2009, 33, 743-765. [CrossRef]

40. Anguelovski, I.; Connolly, J.; Masip, L.; Pearsall, H. Assessing green gentrification in historically disenfranchised neighborhoods: A longitudinal and spatial analysis of Barcelona. Urban Geogr. 2018, 39, 458-491. [CrossRef]

41. Checker, M. Wiped out by the "greenwave": Environmental gentrification and the paradoxical politics of urban sustainability. City Soc. 2011, 23, 210-229. [CrossRef]

42. Dooling, S. Ecological gentrification: A research agenda exploring justice in the city. Int. J. Urban Reg. Res. 2009, 33, 621-639. [CrossRef]

43. Gould, K.A.; Lewis, T.L. Green Gentrification Urban Sustainability and the Struggle for Environmental Justice; Routledge: London, UK, 2017.

44. Döhren, P.; Haase, D. Ecosystem disservices research: A review of the state of the art with a focus on cities. Ecol. Indic. 2015, 52, 490-497. [CrossRef]

45. Badiu, D.L.; Nita, A.; Ioja, C.I.; Nita, M.R. Disentangling the connections: A network analysis of approaches to urban green infrastructure. Urban For. Urban Green. 2019, 41, 211-220. [CrossRef]

46. Artmann, M.; Kohler, M.; Meinel, G.; Gan, J.; Ioja, I.C. How smart growth and green infrastructure can mutually support each other-A conceptual framework for compact and green cities. Ecol. Indic. 2019, 96, 10-22. [CrossRef]

47. Yang, P.P.J.; Lay, O.B. Applying ecosystem concepts to the planning of industrial areas: A case study of Singapore's Jurong Island. J. Clean. Prod. 2004, 12, 1011-1023. [CrossRef] 
48. Eggermont, H.; Balian, E.; Azevedo, J.M.N.; Beumer, V.; Brodin, T.; Claudet, J.; Fady, B.; Grube, M.; Keune, H.; Lamarque, P.; et al. NBS: New Influence for Environmental Management and Research in Europe. GAIA 2015, 24, 243-248. [CrossRef]

49. McPhearson, T.; Pickett, S.T.A.; Grimm, N.; Niemelä, J.; Alberti, M.; Elmqvist, T.; Weber, C.; Haase, D.; Breuste, J.; Qureshi, S. Advancing Urban Ecology toward a Science of Cities. BioScience 2016, 66, 1-15. [CrossRef]

50. Viljoen, A.; Bohn, K. Second Nature Urban Agriculture: Designing Productive Cities, 1st ed.; Routledge: London, UK, 2014. [CrossRef]

51. Essbare Stadt. Available online: http://www.leipziggruen.de/de/2016_EssbareStadt_Uebersicht.asp (accessed on 1 October 2019).

52. Stadt Leipzig. Straßenbaumkonzept: Leipziger WüNschen Sich GrüNere Strassen. 2016. Available online: https: //www.leipzig.de/news/news/strassenbaumkonzept-leipziger-wuenschen-sich-gruenere-strassen/ (accessed on 1 October 2019).

53. Klotz, S. Auenwald-Ein einzigartiges Ökosystem. In Leipzig: Eine Landeskundliche Bestandsaufnahme im Raum Leipzig Landschaften in Deutschland: Werte der deutschen Heimat 78; Denzer, V., Dix, A., Porada, H.T., Eds.; Böhlau: Vienna, Austria, 2015; pp. 136-137.

54. Stadt Leipzig; Bundesamt für Naturschutz (BfN); Naturschutzbund Deutschland (NABU); Landesverband Sachsen E.V. Erhalt Leipziger Auen: Stadt Leipzig und Landesverband Sachsen des NABU e.V. Erhalten Fördermittel aus Bundesprogramm. 2012. Available online: https://www.leipzig.de/news/news/erhaltleipziger-auen-stadt-leipzig-und-landesverband-sachsen-des-nabu-e-v-erhalten-frdermittel-aus/ (accessed on 21 December 2019).

(C) 2020 by the authors. Licensee MDPI, Basel, Switzerland. This article is an open access article distributed under the terms and conditions of the Creative Commons Attribution (CC BY) license (http://creativecommons.org/licenses/by/4.0/). 